\title{
Nove espécies novas do gênero Rineloricaria (Siluriformes, Loricariidae) do rio Uruguai, do sul do Brasil
}

\author{
Miriam S. Ghazzi \\ Setor de Ictiologia, Departamento de Vertebrados, Museu Nacional do Rio de Janeiro - Quinta da Boa Vista, s/n, São Cristovão, 20940- \\ 040 Rio de Janeiro, RJ. (msghazzi@yahoo.com.br)

\begin{abstract}
Nine new species of the genus Rineloricaria (Siluriformes, Loricariidae) from Uruguay river, southern Brazil. Nine new species of Rineloricaria are described from upper and middle rio Uruguay basin in states of Rio Grande do Sul and Santa Catarina, Brazil. Rineloricaria misionera Rodriguez \& Miquelarena, 2005 is the only species currently known from this basin. The new species are diagnosed mainly by abdominal plates arrangement, color pattern, extension of the anterior snout naked area, and fins length. The species described here are endemic to the rio Uruguay. Rineloricaria anitae and $R$. tropeira are restricted to the tributaries of the rio Canoas and the rio Pelotas; $R$. zaina is widely distributed from the confluence of the rio Canoas with the rio Pelotas to the rio Ibicuí; $R$. anhanguapitan is restricted to the rio Passo Fundo; $R$. capitonia occurs in the upper rio Ijuí; $R$. stellata is known from the rio Buricá, rio Ijuí, rio Piratini and rio Ibicuí; $R$. setepovos and $R$. reisi are described from the rio Piratini; and $R$. sanga is only known from the vicinity of Iraí. Comments on the fish diversity of the rio Uruguay and on the variation of abdominal plates in Rineloricaria are made.
\end{abstract}

KEYWORDS. Rineloricaria, Loricariidae, Uruguay river, taxonomy, Neotropical.

RESUMO. Nove espécies novas de Rineloricaria do alto e médio rio Uruguai são descritas nos Estados do Rio Grande do Sul e Santa Catarina, Brasil. Rineloricaria misionera Rodriguez \& Miquelarena, 2005 é a única espécie atualmente conhecida desta bacia. As novas espécies são diagnosticadas principalmente pela disposição das placas no abdome, padrão de colorido, extensão da área nua anterior no focinho e comprimento das nadadeiras. As espécies aqui descritas são endêmicas do rio Uruguai. Rineloricaria anitae e R. tropeira são restritas aos afluentes dos rios Canoas e Pelotas; $R$. zaina é amplamente distribuída da confluência dos rios Canoas com o rio Pelotas até o rio Ibicuí; $R$. anhanguapitan é restrita a bacia do Passo Fundo; $R$. capitonia ocorre no alto rio Ijuí; $R$. stellata é conhecida dos rios Buricá, Ijuí, Piratini e Ibicuí; $R$. setepovos e $R$. reisi são descritas do rio Piratini e $R$. sanga é conhecida apenas dos arredores do município de Iraí. São apresentados comentários sobre a diversidade de espécies no rio Uruguai e em relação à variação de placas no abdome.

PALAVRAS-CHAVE. Rineloricaria, Loricariidae, rio Uruguai, taxonomia, Neotropical.

Entre os muitos representantes da família Loricariidae, encontra-se o gênero Rineloricaria Bleeker, 1862, amplamente distribuído do Panamá na América Central ao norte da Argentina, apresentando 49 espécies válidas (FERraris, 2003; KNAACK, 2003; RodrigueZ \& Miquelarena, 2005). As espécies do gênero habitam uma variedade de hábitats que vão de riachos de montanha com águas rasas, claras, frias e de forte correnteza, a grandes rios ou lagoas em planícies da América do Sul (REIS \& CARDOSO, 2001).

Como integrante da tribo Loricariini, o gênero Rineloricaria foi agrupado por IsBRÜCKER (1979) aos gêneros Ixinandria Isbrücker \& Nijssen in Isbrücker, 1979, Dasyloricaria Isbrücker \& Nijssen in Isbrücker, 1979 e Spatuloricaria Schultz, 1944 na subtribo Rineloricariina Isbrücker, 1979. RAPP PY-DANIEL \& Cox FERNANDEs (2005) em uma hipótese cladística para os Loricariinae indicam Rineloricaria como um gênero parafilético, com suas espécies situadas na base do clado formado pelos outros gêneros da tribo Loricariini. Nesta análise, em contraposição à classificação de IsBRÜCKER (1979), Spatuloricaria não apareceu relacionada a Rineloricaria, estando de fato mais relacionada a outros gêneros. Os gêneros Dasyloricaria e Ixinandria não foram incluídos na análise destas autoras e como não há qualquer hipótese corroborando a classificação de ISBRÜCKER (1979), as relações de parentesco de Rineloricaria com estes gêneros permanecem questionáveis.
Considerando a complexidade taxonômica de Rineloricaria e sua ampla distribuição geográfica, poucos estudos foram feitos sobre o gênero. A última revisão de Rineloricaria foi realizada há um século por REGAN (1904); trabalhos subseqüentes sobre o gênero constituem descrições de espécies novas e redescrições (e. g. ISBRÜCKER \& NIJSSEN, 1976, 1979, 1984; REIS, 1983; Langeani \& Araújo, 1994; Reis \& Cardoso, 2001; Rodriguez \& Miquelarena, 2005) ou compilações de literatura (e. g. GosLINE, 1945; FowLER, 1954; ISBRÜCKER, 1979, 1980, 2001; BuRGESS, 1989; EsCHMEYER, 1998; EVERS \& SeIDEL, 2002; Ferraris, 2003). Contudo, muitas espécies permanecem por serem descritas em diversos sistemas hidrográficos brasileiros (REIS \& CARDOSO, 2001). Em recentes levantamentos nas coleções do Museu de Zoologia da Universidade de São Paulo, Museu Nacional e Museu de História Natural Capão da Imbuia constatouse que ocorrem pelo menos duas espécies não descritas no sistema do rio Ribeira de Iguape, uma no rio Paraíba do Sul, duas nos rios que drenam para a baía da Guanabara e Sepetiba e finalmente os rios Itabapoana (divisa RJ/ES) e Doce abrigam pelo menos uma espécie de Rineloricaria não conhecida. O rio Uruguai também apresenta um número elevado de espécies não conhecidas de Rineloricaria (obs. pess). Considerando todo curso do rio Uruguai, o número de espécies ali encontradas se compara à totalidade das espécies não descritas de rios do escudo brasileiro e rios costeiros. Este grande número 
de espécies não descritas tem gerado problemas aos pesquisadores quanto a elucidar suas relações de parentesco (como demonstrado em RAPP PY-DANIEL \& Cox FERnANDEs 2005), além de dificultar simples revisões regionais e outros estudos de diversos enfoques biológicos.

Sete espécies de Rineloricaria foram descritas do Rio Grande do Sul: R. cadeae (Hensel, 1868) do rio Cadeia, afluente do rio Caí; $R$. strigilata (Hensel, 1868) do rio Santa Cruz; R. microlepidogaster (Regan, 1904), do Rio Grande do Sul, restrita posteriormente à laguna dos Patos (Malabarba, 1989); R. longicauda Reis, 1983 e $R$. quadrensis Reis, 1983 (do banhado do Taim em Rio Grande e da lagoa dos Quadros em Osório, respectivamente); $R$. maquinensis Reis \& Cardoso, 2001 e R. aequalicuspis Reis \& Cardoso, 2001 foram descritas respectivamente, do rio Maquiné e rio Três Forquilhas. Rineloricaria misionera Rodriguez \& Miquelarena, 2005 foi descrita da Província de Misiones na Argentina (sistema do rio Paraná), ocorrendo também no arroio Pepirí Miní, um afluente do rio Uruguai na fronteira do Rio Grande do Sul e Santa Catarina com a Argentina. Além desta espécie, não existe até o momento registro de espécies de Rineloricaria no alto ou médio rio Uruguai.

Levantamentos anteriores da fauna do alto e médio rio Uruguai (BERTOLETTI et al. 1989a, b) e exame das coleções dos museus do Rio Grande do Sul (Museu de Ciências e Tecnologia PUCRS, Museu Anchieta de Porto Alegre e Museu de Ciências Naturais da Fundação Zoobotânica do Rio Grande do Sul) revelaram uma diversidade inesperada de espécies desconhecidas de Rineloricaria. Este trabalho tem como objetivo descrever nove espécies novas de Rineloricaria do alto e médio Uruguai (LUCENA \& KULLANDER, 1992: 158), contribuindo assim com o conhecimento da diversidade do gênero e elevando para 57 o número de espécies conhecidas de Rineloricaria.

\section{MATERIAL E MÉTODOS}

Dados merísticos e morfométricos seguem ISBRÜCKER \& NiJSSEN (1978) e REIS \& CARDOSO (2001), exceto pelos termos "placas abdominais laterais" (SCHAEFER, 1997) conforme utilizado em GHAZZI (2005) e "barbilhão maxilar" (e.g. PEREIRA \& ReIs, 1992) em substituição a "barbilhão rictal". A nomenclatura das séries de placas laterais segue SchAEFER (1997). Contagens são apresentadas nas descrições. As medidas foram feitas com paquímetro digital, sempre que possível no lado esquerdo do exemplar. Os dados morfométricos e merísticos foram analisados estatisticamente com auxílio do programa DATAX 4.2. Os termos osteológicos "supraoccipital" e "pterótico-supracleitro" foram substituídos respectivamente por "parietosupraoccipital" (ARRATIA \& GAYET, 1995) e "pterótico composto" (Aquino \& SchAEFER, 2002). Na descrição da coloração dos raios das nadadeiras, duas terminologias distintas foram empregadas: máculas, para caracterizar manchas semicirculares do tamanho do olho ou pouco menores; pontuações, para caracterizar manchas pequenas, em maior número por raio e menores que o olho. O caráter "ponta do focinho com área nua estendida posteriormente", presente nas espécies, é representado em Langeani \& Araujo (1994: fig. 2A). Nas diagnoses, comparam-se as espécies aqui descritas com aquelas de outros sistemas hidrográficos (sistemas costeiros do sul ao sudeste do Brasil, sistema costeiro do Uruguai, sistema Paraná-Paraguai). Diferenças não citadas nas diagnoses podem ser vistas na Tabela I.

$\mathrm{O}$ material examinado pertence às seguintes instituições: ANSP, Academy of Natural Science, Philadelphia; BMNH, Natural History Museum, London; MAPA, Museu Anchieta, Porto Alegre; MCN, Museu de Ciências Naturais da Fundação Zoobotânica do Rio Grande do Sul, Porto Alegre; MCNI, Museo de Ciencias Naturales, Universidad Nacional de Salta, Salta; MCP, Museu de Ciências e Tecnologia PUCRS, Porto Alegre; MHNCI, Museu de História Natural Capão da Imbuia, Curitiba; MNRJ, Museu Nacional, Rio de Janeiro; MZUSP, Museu de Zoologia da Universidade de São Paulo, São Paulo; NMW, Naturhistorisches Museum, Wien; UFRGS, Departamento de Zoologia da UFRGS, Porto Alegre; ZMA, Instituüt voör Taxonomische Zoölogie (Zoölogisch Museum), Amsterdam.

\section{RESULTADOS}

Chave para as espécies de Rineloricaria do alto e médio rio Uruguai

1. Região da cintura escapular nua, apenas com pequenas placas laterais ou completamente coberta por pequenas placas poligonais; abdome com cobertura de placas variável ou totalmente coberto por placas

1'. Região da cintura escapular e abdome totalmente nus inclusive sem placa pré-anal

Rineloricaria setepovos sp. nov.

2. Abdome totalmente coberto com 3-6 séries de placas; região da cintura escapular coberta por pequenas placas menores e mais numerosas ........................ 6

2'. Abdome com padrão de cobertura variável de placas, em séries irregulares; região da cintura escapular totalmente nua ou com um pequeno conjunto de placas diminutas logo abaixo das aberturas branquiais

3. Cintura escapular apenas com um pequeno conjunto de placas diminutas logo abaixo das aberturas branquiais

3'. Região da cintura escapular nua, sem estes conjuntos de placas ......................................................... 5

4. Placa pré-anal precedida por placas poligonais a ovaladas, diminuindo no sentido anterior; placas abdominais laterais não contatando as séries abdominais; distância interorbital de 17\%-19,9\% no comprimento da cabeça

Rineloricaria reisi sp. nov.

4'. Placa pré-anal precedida por três placas grandes, anteriormente o abdome pode ser nu ou com 1-3 séries de placas elipsoidais menores que aquelas que precedem a pré-anal; apenas anteriormente as placas abdominais laterais não contatam as séries abdominais; distância interorbital de 21,5\%-25,6\% no comprimento da cabeça

Rineloricaria capitonia sp. nov. 
5. Séries irregulares de placas abdominais atingindo o nível da inserção posterior da nadadeira peitoral iniciadas por 1-3 placas maiores, geralmente retangulares, em contato lateral com a primeira placa abdominal lateral; ponta do focinho com área nua estendida posteriormente; nadadeiras dorsal e anal com faixa distal cinza-escura

Rineloricaria anhanguapitan sp. nov.

5'. Séries irregulares de placas abdominais não atingindo o nível da inserção posterior da nadadeira peitoral, sem contato com as primeiras placas abdominais laterais; ponta do focinho com área nua ovalada, não estendida; nadadeiras sem faixas

Rineloricaria tropeira sp. nov.

6. Ponta do focinho com área nua estreita estendida posteriormente, em geral ultrapassando o poro mais anterior do canal sensorial infraorbital; 3-5 séries de placas abdominais; região de cintura escapular podendo apresentar pequenas falhas na cobertura Rineloricaria stellata sp. nov.

6'. Ponta do focinho com área nua ovalada não atingindo o poro mais anterior do canal sensorial infraorbital, 3 ou mais séries de placas abdominais ... 7

7. Raio indiviso superior da caudal continuado em filamento; três séries de placas abdominais; cristas da cabeça e pré-dorsais conspícuas

Rineloricaria sanga sp. nov.

7'. Raio indiviso superior da caudal sem filamento; 5-6 séries de placas abdominais; cristas da cabeça e pré-dorsais suaves ............................................ 8

8. Nadadeiras peitorais atingindo o primeiro terço das nadadeiras pélvicas, estas tocando ou ultrapassando a origem da nadadeira anal ....

Rineloricaria zaina sp. nov.

8'. Nadadeiras peitorais atingindo a inserção ou pouco além nas nadadeiras pélvicas, estas não tocando a inserção da nadadeira anal

Rineloricaria anitae sp. nov.

\section{Rineloricaria tropeira sp.nov. \\ (Figs.1, 2)}

Holótipo, Brasil, Rio Grande do Sul: Vacaria (arroio Passo do Carro, drenagem do rio Quatis, afluente do rio Pelotas, estrada Vacaria/Bom Jesus, 28 $8^{\circ} 36^{\prime} \mathrm{S} \quad 50^{\circ} 43^{\prime} \mathrm{W}$ ), sexo indeterminado, $88,1 \mathrm{~mm} \mathrm{CP}$, 4.V.1985, C. A. S. Lucena, L. R. Malabarba \& R. E. Reis cols. (MCP 19684). Parátipos, Brasil, Rio Grande do Sul: mesmos dados do holótipo, 20 ex., 54,8$77,5 \mathrm{~mm}$ CP (MCP 11533); Vacaria (nascente do arroio Lageado Bonito, drenagem do rio Quatis, rio Pelotas, estrada Vacaria/Bom Jesus, $\left.28^{\circ} 38^{\prime} \mathrm{S} 50^{\circ} 33^{\prime} \mathrm{W}\right), 6$ ex., 46,0-83,2mm CP, 4.V.1985, C.

Tabela I. Ocorrência de características diagnósticas em Rineloricaria do leste da América do Sul e bacia do Prata (+, presença e ?, não verificado). Ver discussão para detalhes do padrão de colorido de $R$. strigilata (Hensel, 1868), R. cacerensis (Miranda-Ribeiro, 1912), R. hoehnei (Miranda-Ribeiro, 1912) e R. parva (Boulenger, 1895).

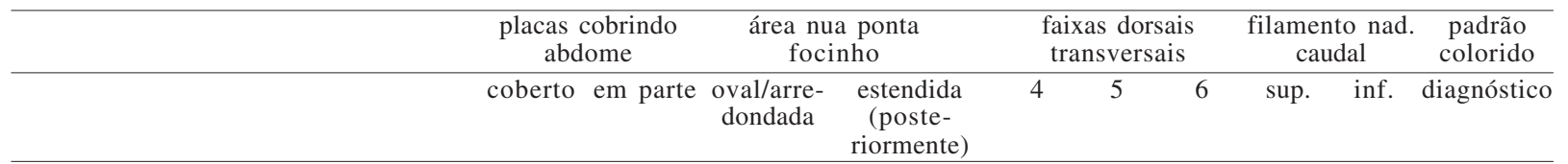

\section{Espécie}

R. aequalicuspis Reis \& Cardoso, 2001

$R$. anhanguapitan sp. nov.

$R$. anitae sp. nov.

R. cacerensis (Miranda-Ribeiro, 1912)

$R$. cadeae Hensel, 1868

$R$. capitonia sp. nov.

R. cubataonis (Steindachner, 1907)

R. felipponei (Fowler, 1943)

R. henselii (Steindachner, 1907)

R. hoehnei (Miranda-Ribeiro, 1912)

R. jaraguensis (Steindachner, 1907)

R. kronei (Miranda-Ribeiro, 1912)

$R$. latirostris (Boulenger, 1900)

R. longicauda Reis, 1983

R. maquinensis Reis \& Cardoso, 2001

R. microlepidogaster (Regan, 1904)

R. misionera Rodriguez \& Miquelarena, 2005

R. nigricauda (Regan, 1904)

$R$. pareiacantha (Fowler, 1943)

R. parva (Boulenger, 1895)

R. pentamaculata (Langeni \& Araújo, 1994)

R. quadrensis Reis, 1983

$R$. reisi sp. nov.

$R$. sanga $\mathrm{sp}$. nov.

$R$. setepovos $\mathrm{sp}$. nov.

R. steindachneri (Regan, 1904)

$R$. stellata $\mathrm{sp}$. nov.

R. strigilata (Hensel, 1868)

$R$. thrissoceps (Fowler, 1943)

$R$. tropeira $\mathrm{sp}$. nov.

$R$. zaina $\mathrm{sp}$. nov.

\begin{tabular}{|c|c|c|c|c|c|c|c|c|c|}
\hline & + & + & & & + & & & & \\
\hline & + & & + & & + & & & & \\
\hline+ & & + & & & + & & & & \\
\hline+ & & + & & & + & & + & + & + \\
\hline+ & & & + & & + & & & & \\
\hline & + & & + & & + & & & & \\
\hline & + & + & & + & & & & & \\
\hline+ & & + & & & + & & & & \\
\hline+ & & + & & + & & & & & \\
\hline+ & & + & & & + & & + & & + \\
\hline+ & & + & & + & & & & & \\
\hline+ & & + & & + & & & + & & \\
\hline+ & & + & & & + & + & + & & \\
\hline+ & & & + & & + & & & & \\
\hline & + & + & & & + & & & & \\
\hline+ & & + & & & + & & & & \\
\hline & + & + & & & + & & & & \\
\hline+ & & & + & & + & & + & & \\
\hline+ & & & + & & + & & & & \\
\hline+ & & $?$ & & $?$ & $?$ & $?$ & + & + & + \\
\hline+ & & & + & & + & & + & & \\
\hline+ & & + & & & + & & & & \\
\hline & + & + & & & + & & & & \\
\hline+ & & + & & & + & & + & & \\
\hline & + & + & & & & + & & & \\
\hline+ & & + & & & + & & + & & \\
\hline+ & & & + & & + & & + & & \\
\hline+ & & + & & & + & & & & + \\
\hline+ & & + & & $?$ & $?$ & $?$ & & & \\
\hline & + & + & & & + & & & & \\
\hline+ & & + & & & + & & & & \\
\hline
\end{tabular}




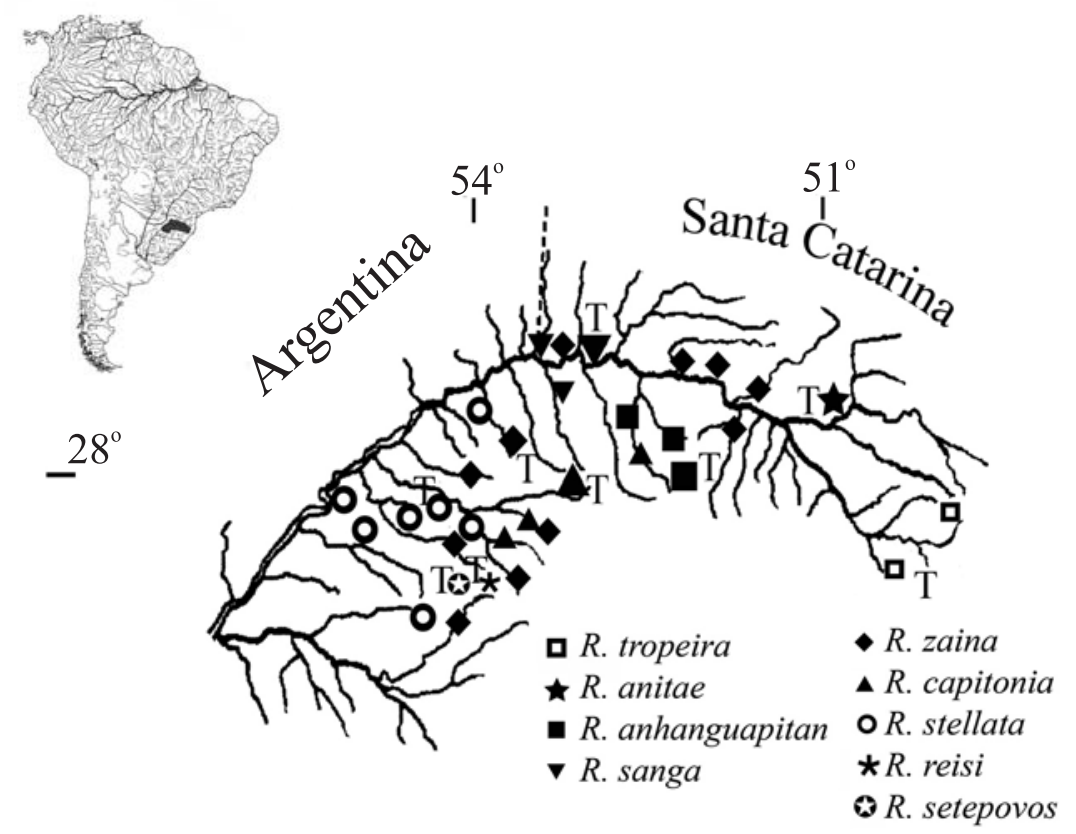

Fig. 1. Distribuição das espécies de Rineloricaria no alto e médio rio Uruguai. As localidades tipo das espécies são representadas por um "T". Um símbolo pode representar mais de um lote.

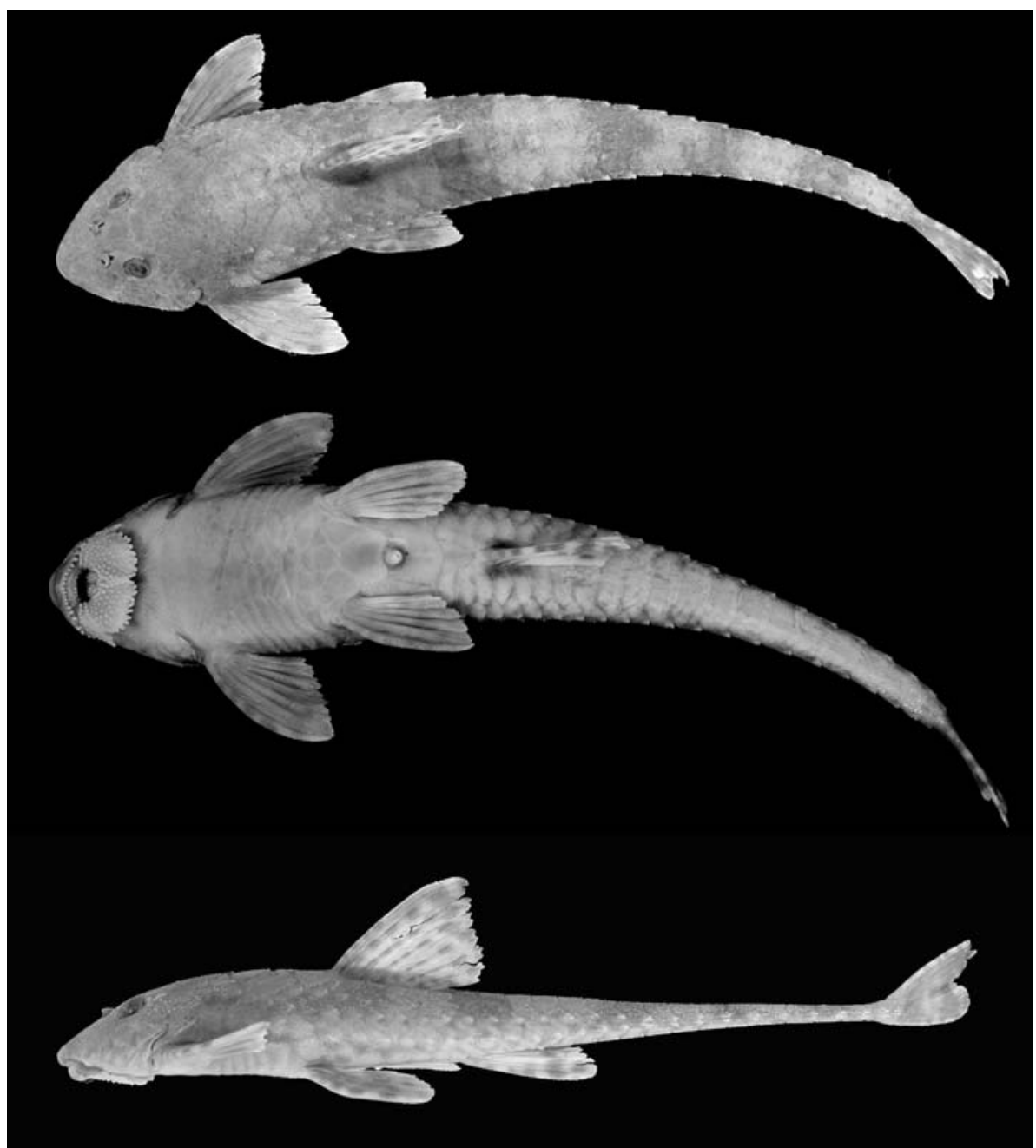

Fig. 2. Rineloricaria tropeira sp. nov. holótipo MCP 19684, sexo indeterminado, 88,1 mm CP, arroio Passo do Carro (drenagem do rio Quatis, afluente do rio Pelotas) estrada Vacaria/Bom Jesus, Vacaria (28³6'S 5043'W), Rio Grande do Sul. 
A. S. Lucena, L. R. Malabarba \& R. E. Reis cols. (MCP 11530); Vacaria (arroio Cachoeirinha, drenagem do rio Quatis, afluente do rio Pelotas, estrada Vacaria/Bom Jesus), 62,9mm CP, 4.V.1985, C. A. S. Lucena, L. R. Malabarba \& R. E. Reis cols. (MCP 11550) Não-parátipos, Brasil, Santa Catarina: Urubici (rio Urubici, junto à ponte ao sul de Urubici, 28 ${ }^{\circ} 1^{\prime} 37^{\prime}$ 'S 49 35'22'”W), 2 ex., 74,6-79,9mm CP (MNRJ 19037); Urubici (arroio afluente do rio Canoas a leste da Vila São José na estrada para a Serra do Corvo Branco, 28³'33"S 49²5'42”W), 95,9mm CP (MCP 22379); Urubici (rio Urubici junto à ponte ao sul de Urubici, $28^{\circ} 1$ '37's 49³5'23”W), 102,8mm CP (MCP 22382); Lages, 2 ex., 102 $113 \mathrm{~mm}$ CP (MNRJ 21284)

Diagnose. Rineloricaria tropeira se distingüe das demais espécies do gênero pela região da cintura escapular nua e abdome parcialmente coberto por placas, com placa pré-anal antecedida por um conjunto de séries irregulares de placas não atingindo a altura da inserção do último raio ramificado da nadadeira peitoral. Além disso, a seguinte combinação ajuda a diferenciá-la das outras espécies: ponta do focinho com uma área nua ovalada não se estendendo para trás, cristas da cabeça e cristas dorsais inconspícuas e nadadeiras peitorais atingindo o primeiro terço das pélvicas. Rineloricaria tropeira assemelha-se a $R$. misionera pela região anterior do abdome sem placas, mas apresenta pedúnculo caudal mais longo (51,9-57,4\% vs. 44,1-53,1\% no CP) e não apresenta pequenas placas na cintura escapular como pode ocorrer em $R$. misionera.

Descrição. Dados morfométricos apresentados na Tabela II. Corpo achatado, fortemente deprimido no pedúnculo caudal, afilando-se posteriormente a partir das nadadeiras peitorais. Perfil dorsal levemente convexo da ponta do focinho à inserção da nadadeira dorsal, declinando levemente até tornar-se reto no final do pedúnculo caudal.

Perfil anterior da cabeça em vista dorsal aproximadamente triangular. Odontodes pequenos. Ponta do focinho com área nua ovalada não alcançando o poro mais anterior do canal sensorial infraorbital na margem inferior do focinho. Crista inconspícua originada na ponta do focinho, bifurcando-se entre as narinas. Par de cristas divergentes do parieto-supraoccipital e pré-dorsais suaves. Borda superior da órbita baixa; entalhe pós-orbital pequeno; órbita 1,2 vezes na distância interorbital. Olho arredondado a ovalado, íris parcialmente coberta por um pequeno divertículo.

Lábio inferior bem desenvolvido, coberto com pequenas papilas e margem com franja discreta; duas fileiras de papilas bem visíveis separam o lábio inferior do superior; barbilhão maxilar presente com tamanho aproximado ao do sulco pós-orbital. Dentes afilados e bilobados com as cúspides internas mais longas; 5-9 dentes no pré-maxilar, 6-8 dentes no dentário maiores que os superiores.

Trinta placas na série média (placas laterais da série pós-cleitral). Placas da série média e série médio-ventral com quilhas ásperas, confluentes, com odontodes conspícuos nas extremidades, coalescendo-se nas últimas 10-13 placas. Linha lateral completa, os poros abrindo-se na série média de placas e estendendo-se até a placa central das placas supracaudais. Seis a oito placas abdominais laterais, localizadas entre a inserção do último raio ramificado das nadadeiras peitorais e inserção das nadadeiras pélvicas.

Tabela II. Dados morfométricos do holótipo e parátipos de Rineloricaria tropeira, R. anitae e R. anhanguapitan (n, número de exemplares excluíndo holótipo).

\begin{tabular}{|c|c|c|c|c|c|c|c|c|c|c|c|c|}
\hline & \multicolumn{4}{|c|}{ R. tropeira } & \multicolumn{3}{|c|}{ R. anitae } & \multicolumn{5}{|c|}{ R. anhangapitan } \\
\hline & \multirow[t]{2}{*}{ holótipo } & \multicolumn{3}{|c|}{ parátipos } & \multirow[t]{2}{*}{ holótipo } & \multicolumn{3}{|c|}{ parátipos } & \multirow[t]{2}{*}{ holótipo } & \multicolumn{3}{|c|}{ parátipos } \\
\hline & & $\mathrm{n}$ & variação & média & & $\mathrm{n}$ & variação & média & & $\mathrm{n}$ & variação & média \\
\hline $\begin{array}{l}\text { Comprimento padrão }(\mathrm{mm}) \\
\text { Comprimento padrão }(\%)\end{array}$ & 88,1 & 15 & $46,0-83,2$ & 66,5 & 106,3 & 5 & $53,1-117,4$ & 89,0 & 105,8 & 20 & $89,5-126,5$ & 105,1 \\
\hline Comprimento da cabeça & 24,0 & 15 & $22,5-24,5$ & 23,6 & 23,7 & 5 & $21,7-23,0$ & 22,6 & 25,5 & 20 & $23,8-25,7$ & 24,9 \\
\hline Largura cleitral & 19,1 & 15 & $17,6-19,6$ & 18,7 & 19,7 & 5 & $17,8-19,2$ & 18,5 & 22,2 & 20 & $20,0-22,2$ & 21,2 \\
\hline Comprimento pré-dorsal & 35,1 & 15 & $32,6-35,1$ & 33,7 & 34,7 & 5 & $31,8-34,3$ & 33,4 & 36,4 & 20 & $34,3-37,2$ & 35,8 \\
\hline $\begin{array}{l}\text { Comprimento raio } \\
\text { indiviso da dorsal }\end{array}$ & 17,6 & 15 & $19,5-22,8$ & 20,9 & 21,1 & 5 & $18,5-21,6$ & 19,7 & 21,7 & 20 & $18,8-22,6$ & 21,1 \\
\hline $\begin{array}{l}\text { Comprimento raio } \\
\text { indiviso da anal }\end{array}$ & 16,0 & 15 & $14,8-19,1$ & 17,4 & 16,6 & 5 & $14,7-16,6$ & 15,3 & 16,4 & 19 & $14,7-18,0$ & 16,4 \\
\hline $\begin{array}{l}\text { Comprimento raio } \\
\text { indiviso da peitoral }\end{array}$ & 17,6 & 15 & $16,2-19,5$ & 17,7 & 17,7 & 5 & $16,2-18,0$ & 16,9 & 18,0 & 20 & $16,0-20,1$ & 17,8 \\
\hline $\begin{array}{l}\text { Comprimento raio } \\
\text { indiviso da pélvica }\end{array}$ & 15,2 & 15 & $14,5-17,9$ & 16,0 & 14,6 & 5 & $12,8-15,2$ & 14,3 & 15,0 & 20 & $13,8-17,2$ & 15,5 \\
\hline $\begin{array}{l}\text { Comprimento raio indiviso } \\
\text { superior caudal }\end{array}$ & 15,9 & 13 & $12,9-18,0$ & 15,6 & 16,3 & 5 & $14,6-17,4$ & 15,9 & 15,9 & 13 & $14,5-17,5$ & 16,0 \\
\hline $\begin{array}{l}\text { Comprimento raio indiviso } \\
\text { inferior caudal }\end{array}$ & 14,3 & 13 & $12,1-16,9$ & 14,5 & 13,6 & 5 & $11,3-14,7$ & 13,2 & 14,2 & 13 & $12,3-15,0$ & 14,0 \\
\hline Comprimento torácico & 15,6 & 15 & $12,5-14,9$ & 13,8 & 13,2 & 5 & $13,4-15,2$ & 14,3 & 14,8 & 20 & $12,5-17,9$ & 15,1 \\
\hline Comprimento abdominal & 17,8 & 15 & $15,2-17,5$ & 16,2 & 16,9 & 5 & $14,7-17,2$ & 16,3 & 18,7 & 20 & $17,5-19,0$ & 18,2 \\
\hline Comprimento pós-dorsal & 55,4 & 15 & $54,4-58,4$ & 56,8 & 56,4 & 5 & $56,0-58,9$ & 57,6 & 51,4 & 20 & $51,4-55,4$ & 53,3 \\
\hline Comprimento pedúnculo caudal & 51,9 & 15 & $52,9-57,4$ & 54,9 & 52,9 & 5 & $52,9-55,0$ & 54,2 & 48,5 & 20 & $48,5-52,2$ & 50,4 \\
\hline Altura corpo nadadeira dorsal & 11,5 & 15 & $9,7-11,5$ & 10,5 & 11,2 & 5 & $9,8-13,1$ & 11,3 & 10,1 & 20 & $9,2-13,7$ & 11,1 \\
\hline $\begin{array}{l}\text { Largura corpo nadadeira anal } \\
\text { Comprimento da cabeça }(\%)\end{array}$ & 12,0 & 15 & $10,1-12,1$ & 11,2 & 11,5 & 5 & $10,2-12,5$ & 11,3 & 11,6 & 20 & $11,2-13,1$ & 12,0 \\
\hline Altura da cabeça & 46,0 & 15 & $42,4-50,0$ & 46,1 & 43,7 & 5 & $40,1-45,0$ & 43,5 & 45,6 & 20 & $39,1-45,6$ & 41,6 \\
\hline Comprimento do focinho & 49,3 & 15 & $46,5-52,0$ & 48,6 & 48,8 & 5 & $48,8-50,4$ & 49,6 & 49,3 & 20 & $47,9-51,1$ & 49,0 \\
\hline Diâmetro orbital & 22,3 & 15 & $19,2-23,4$ & 21,0 & 23,0 & 5 & $21,7-22,4$ & 22,1 & 22,2 & 20 & $21,1-23,8$ & 22,3 \\
\hline Distância interorbital & 24,2 & 15 & $24,0-25,8$ & 24,9 & 23,4 & 5 & $21,7-23,3$ & 22,5 & 23,7 & 20 & $21,7-25,5$ & 23,7 \\
\hline
\end{tabular}


Abdome revestido posteriormente pela placa préanal bem desenvolvida, margeada anteriormente por três placas poligonais. Antecedem este conjunto séries irregulares de placas, não alcançando a altura da inserção do último raio da nadadeira peitoral. Restante do abdome e região escapular sem placas.

Dorsal i+7; raio indiviso menor que comprimento da cabeça. Peitoral i+6; quando adpressa ao corpo, atingindo o primeiro terço da nadadeira pélvica. Pélvica i+5; podendo atingir inserção da nadadeira anal. Anal $\mathrm{i}+5$. Caudal $\mathrm{i}+10+\mathrm{i}$; raio indiviso superior da nadadeira caudal maior que o raio inferior; borda posterior da nadadeira caudal levemente côncava.

Colorido em álcool. Superfície dorsal castanha, mais escura na cabeça e numa faixa transversal difusa na região occipital; pontuações pequenas castanho-escuras por todo corpo. Lateral da cabeça com pigmentação castanho-escura formando padrão marmóreo. Cinco faixas alargadas castanho-escuras transversais, sendo a primeira na base da nadadeira dorsal e a quinta no final do pedúnculo. Raios indivisos das nadadeiras com pontuações castanho- escuras; membranas hialinas ou de coloração amarelada, apresentando coloração castanho-clara na nadadeira dorsal e formando faixa distal inconspícua. Pontuações nos raios da nadadeira dorsal alinhadas em estrias oblíquas. Base da nadadeira caudal escura, margem da nadadeira com pigmentação castanho-escura em uma faixa, não atingindo a margem desta nadadeira. Superfície ventral amarelada; alguns exemplares com pigmentação castanho-escura nas extremidades laterais do pedúnculo caudal.

Distribuição. Afluentes dos rios Pelotas e Canoas, alto rio Uruguai.

Etimologia. O nome específico tropeira, substantivo em aposição, é dado em homenagem aos tropeiros que por muitos anos viajaram transportando cavalos e mulas pela região de ocorrência da espécie.

\section{Rineloricaria anitae sp. nov. (Figs 1,3)}

Holótipo, Brasil, Santa Catarina: Campos Novos (rio Canoas entre Vargem Grande e São José do Cerrito, 27³3'S $\left.50^{\circ} 53^{\prime} \mathrm{W}\right)$, o’ $^{\circ} 106,3 \mathrm{~mm} \mathrm{CP}, 10 . \mathrm{IX} .1988$, A. Ramires, A.

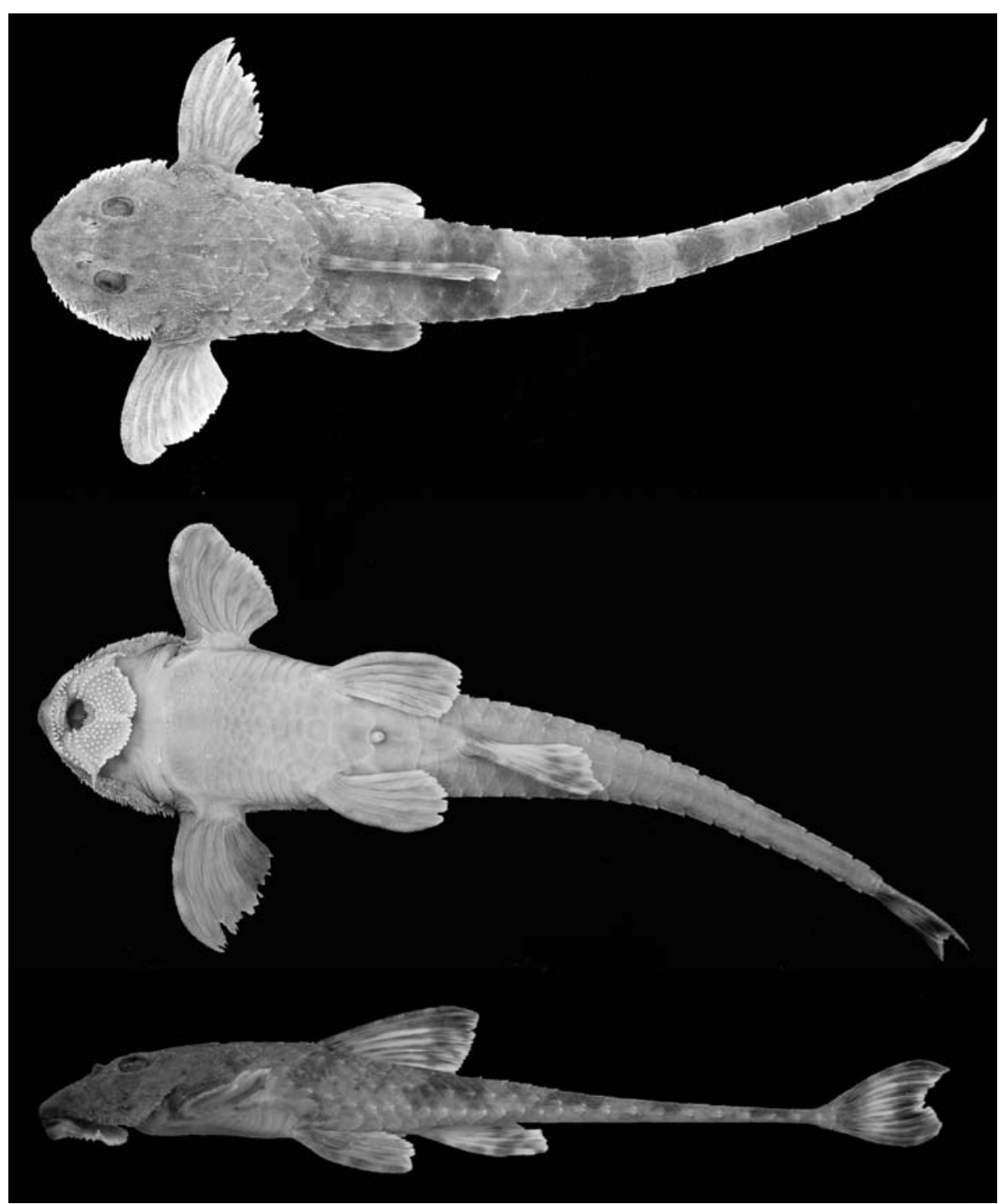

Fig. 3. Rineloricaria anitae sp. nov. holótipo MCP 19685, ơ, 106,3 mm CP, rio Canoas entre Vargem Grande e São José do Cerrito,

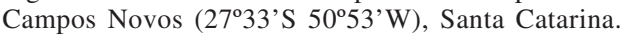


Bergmann, P. Azevedo \& E. Pereira cols. (MCP 19685). Parátipos, Brasil, Santa Catarina: mesmos dados do holótipo, 4 ex., 53,1108,9mm CP (MCP 12342); mesma localidade do holótipo, 117,4mm CP, 12-13.XI.1988, C. Lucena, P. Azevedo, E. Pereira \& A. Ramires cols. (MCP 12764).

Diagnose. Rineloricaria anitae se distingue das demais espécies do gênero pela seguinte combinação de caracteres: ponta do focinho com uma área nua ovalada não se estendendo para trás; olho uma vez na distância interorbital; abdome completamente coberto por 5-6 séries de placas, precedidas por placas menores na região da cintura escapular; nadadeiras peitorais alcançando no máximo o primeiro terço das pélvicas; pélvicas alcançando a inserção da nadadeira anal; região distal da nadadeira caudal com uma faixa transversal escura. Esta espécie assemelha-se a $R$. jaraguensis (Steindachner, 1909) pelo abdome coberto de placas, mas diferencia-se facilmente pelo menor tamanho da cabeça $(21,7-23 \%$ vs. $25,9-26,6 \%$ no CP); diferencia-se de $R$. thrissoceps (Fowler, 1943) (também com abdome coberto) pela maior distância interorbital (21,7-23,3\% vs. 19,8\% no CC); R. quadrensis, R. felipponei (Fowler, 1943) e R. steindachneri (Regan, 1904) apresentam três e quatro séries de placas no abdome. Assemelha-se a R. henselli (Steindachner, 1907) pelo número de placas nas séries abdominais (cinco), mas diferencia-se por apresentar cinco faixas transversais no dorso $v s$. quatro faixas; assemelha-se a $R$. microlepidogaster (5-6 séries de placas abdominais), mas diferencia-se por esta apresentar uma pequena área nua ovalada (observado em exemplares adultos) entre as últimas placas abdominais laterais e as séries abdominais e por ter as placas abdominais laterais uniformes na região mediana do abdome $v s$. placas na região mediana mais alongadas que as placas adjacentes. Além disso, $R$. anitae apresenta as nadadeiras peitorais e pélvicas curtas, apenas tocando a base das nadadeiras adjacentes ( $v s$. nadadeiras ultrapassando a base das nadadeiras adjacentes em $R$. microlepidogaster).

Descrição. Dados morfométricos apresentados na Tabela II. Corpo achatado, fortemente deprimido no pedúnculo caudal, afilando-se posteriormente a partir das nadadeiras peitorais. Perfil dorsal levemente convexo da ponta do focinho à inserção da nadadeira dorsal, declinando levemente até tornar-se reto no final do pedúnculo caudal.

Perfil anterior da cabeça em vista dorsal arredondado. Odontodes pequenos, mas claramente arranjados em linhas na cabeça e região pré-dorsal. Odontodes proeminentes nas laterais da cabeça dos machos sexualmente maduros. Ponta do focinho com pequena área nua ovalada, não alcançando o poro mais anterior do canal sensorial infraorbital na margem inferior do focinho. Crista inconspícua originada na ponta do focinho, bifurcando-se entre as narinas. Par de cristas divergentes do parieto-supraoccipital e pré-dorsais suaves, pronunciadas em relação à crista do focinho. Borda superior da órbita saliente, estendendo-se anteriormente; entalhe pós-orbital pouco menor que a metade do olho; órbita uma vez na distância interorbital. Olho arredondado a ovalado, íris parcialmente coberta por um pequeno divertículo.

Lábio inferior bem desenvolvido, coberto com pequenas papilas e margem com franja discreta; duas fileiras de papilas bem visíveis separam o lábio inferior do superior; barbilhão maxilar presente com tamanho aproximado ao do sulco pós-orbital. Dentes afilados e bilobados com as cúspides internas mais longas; 5-8 dentes no pré-maxilar, 5-8 dentes no dentário maiores que os superiores.

Vinte e nove placas na série média (placas laterais da série pós-cleitral). Placas da série média e série médioventral com quilhas ásperas, confluentes, com odontodes conspícuos nas extremidades, coalescendo-se nas últimas 11-13 placas. Linha lateral completa, os poros abrindo-se na série média de placas e estendendo-se até a placa central das placas supracaudais.

Sete a oito placas abdominais laterais, localizadas entre o último raio ramificado das nadadeiras peitorais e inserção das nadadeiras pélvicas. Abdome revestido posteriormente pela placa pré-anal, anteriormente margeada com três a cinco placas. Anteriormente a este complexo 5-6 séries de placas pequenas. Região escapular revestida de placas menores que as abdominais e bastante numerosas.

Dorsal i+7; raio indiviso menor que comprimento da cabeça. Peitoral i+6; quando adpressa ao corpo, atingindo no máximo o primeiro terço da nadadeira pélvica. Pélvica i+5; alcançando a inserção da nadadeira anal. Anal $\mathrm{i}+5$. Caudal $\mathrm{i}+10+\mathrm{i}$; raio indiviso superior da nadadeira caudal pouco maior que o raio inferior; borda posterior da nadadeira caudal levemente côncava.

Colorido em álcool. Superfície dorsal castanha mais escura na cabeça e numa faixa transversal difusa na região occipital. Lateral da cabeça com manchas escuras de forma e padrão irregular. Cinco faixas castanho-escuras transversais, sendo a primeira na base da nadadeira dorsal e a quinta no final do pedúnculo. Raios indivisos das nadadeiras com máculas escuras. Pontuações discretas nos raios indivisos da nadadeira dorsal formando estrias irregulares, pigmentação esta mais acentuada próxima à margem distal. Nadadeira anal com pigmentação acentuada na margem distal. Base da nadadeira caudal escurecida; margem distal da nadadeira com faixa alargada castanho-escura. Superfície ventral amarelada.

Distribuição. Conhecida somente da localidade-tipo.

Etimologia. O nome específico anitae, substantivo no genitivo, é dado em homenagem a Anita Garibaldi, personagem da Revolução Farroupilha

\section{Rineloricaria anhaguapitan sp. nov.} (Figs. 1, 4)

Holótipo, Brasil, Rio Grande do Sul: Coxilha (rio Butiá na Granja Tagliari, afluente do rio Passo Fundo, localidade Entre

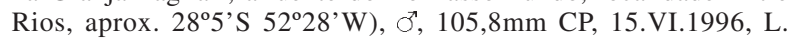
Hahn, L. F. Câmara, I. C. Souza \& J. Bruschi cols. (MCP 21070). Parátipos, Brasil, Rio Grande do Sul: mesmos dados do holótipo, 2 ex., 99,5-104,6mm CP (MCP 21071); idem, 96,5mm CP (MCP 21072); Entre Rios do Sul (barragem do rio Passo Fundo, 27040'9"S 5245'25"W), 2 ex., 98,8-104,3mm CP,17.XII.1996, L. Hahn, L. F. Câmara, I. C. Souza \& J. Bruschi cols. (MCP 21073); idem, 119,7 mm CP (MCP 21074); idem, 120,8mm CP (MCP 21075); idem, 3 ex. (MCP 21076); Sertão (rio Butiá, afluente do rio Passo Fundo, Granja Borella, aprox. 28²'S 52³0'W), 115,5mm CP, 8.IX.1996, L. Hahn, L. F. Câmara, I. C. Souza \& J. Bruschi cols. (MCP 21077); idem localidade anterior, 3 ex., 106,2107,7mm CP, 16.VI.1996, L. Hahn, L. F. Câmara, I. C. Souza \& J. Bruschi cols. (MCP 21078); Coxilha (rio Caraguatá, afluente do rio Passo Fundo, 28 $\left.8^{\circ} 13^{\prime \prime S} 52^{\circ} 18^{\prime} 9^{\prime \prime W}\right), 2$ ex., 102-106mm 
CP, 27.VII.1995, L. Hahn \& L. F. Câmara cols. (MCP 21079); Entre Rios do Sul (barragem do rio Passo Fundo em frente à taipa, 27³3'50'S 52 44'16”'W), 4 ex., 110,2-123,8mm CP, 31.V.1998, L. Hahn, O. Brustolin \& L. F. Câmara cols. (MCP 22445); Passo Fundo (rio Passo Fundo na britagem Farroupilha, ao lado da perimetral leste, $\left.28^{\circ} 19^{\prime} \mathrm{S} 52^{\circ} 21^{\prime} \mathrm{W}\right), 126,5 \mathrm{~mm}$ CP, 3.I.2003, W. Bruschi Jr. \& J. F. P. Silva cols. (MCP 31781); Coxilha (rio Caraguatá, $\left.28^{\circ} 7^{\prime} \mathrm{S} 52^{\circ} 24^{\prime} \mathrm{W}\right), 89,5 \mathrm{~mm}$ CP, L. F. Câmara col. (MCP 33934); Passo Fundo (arroio afluente do rio Passo Fundo, barragem da CORSAN, cerca $1 \mathrm{~km}$ da BR285, $28^{\circ} 19^{\prime} \mathrm{S} 52^{\circ} 18^{\prime} \mathrm{W}$ ), 102,1mm CP, 3.I.2003, W. Bruschi Jr. \& J. F. P. Silva cols. (MCP 31762); Passo Fundo (rio Passo Fundo a jusante da barragem da CORSAN, $\left.28^{\circ} 19^{\prime} \mathrm{S} 52^{\circ} 18^{\prime} \mathrm{W}\right), 5$ ex., 101,1-104,9mm CP, 3.I.2003, W. Bruschi Jr. \& J. F. P. Silva cols. (MCP 31782).

Diagnose. Rineloricaria anhanguapitan se distingüe das demais espécies do gênero pela região da cintura escapular nua e abdome completamente coberto por 3-5 séries de placas não atingindo a altura da inserção das nadadeiras peitorais, com uma placa alongada anterior ou duas a três mais curtas que esta, contatando lateralmente a primeira placa abdominal lateral. Além disso, a seguinte combinação ajuda a diferenciá-la das outras espécies: ponta do focinho com área nua estendida posteriormente alcançando o poro mais anterior do canal sensorial infraorbital, nadadeiras peitorais atingindo o primeiro terço das pélvicas, nadadeiras dorsal, anal e caudal portando distalmente mancha castanho-escura transversal. Rineloricaria anhanguapitan assemelhase a $R$. misionera pela região escapular sem placas, mas diferencia-se pela área nua do focinho estendida posteriormente $v s$. não estendida e pela mancha distal das nadadeiras dorsal e anal ausente em $R$. misionera.

Descrição. Dados morfométricos apresentados na Tabela II. Corpo achatado, fortemente deprimido no pedúnculo caudal, afilando-se posteriormente a partir das nadadeiras peitorais. Perfil dorsal levemente convexo da ponta do focinho à inserção da nadadeira dorsal, declinando levemente até tornar-se reto no final do pedúnculo caudal.

Perfil anterior da cabeça em vista dorsal aproximadamente triangular. Odontodes arranjados em linhas conspícuas na cabeça e proeminentes nas laterais da cabeça dos machos maduros. Ponta do focinho com área nua estendida posteriormente, alcançando o poro mais anterior do canal sensorial infraorbital na margem inferior do focinho. Crista originada na ponta do focinho

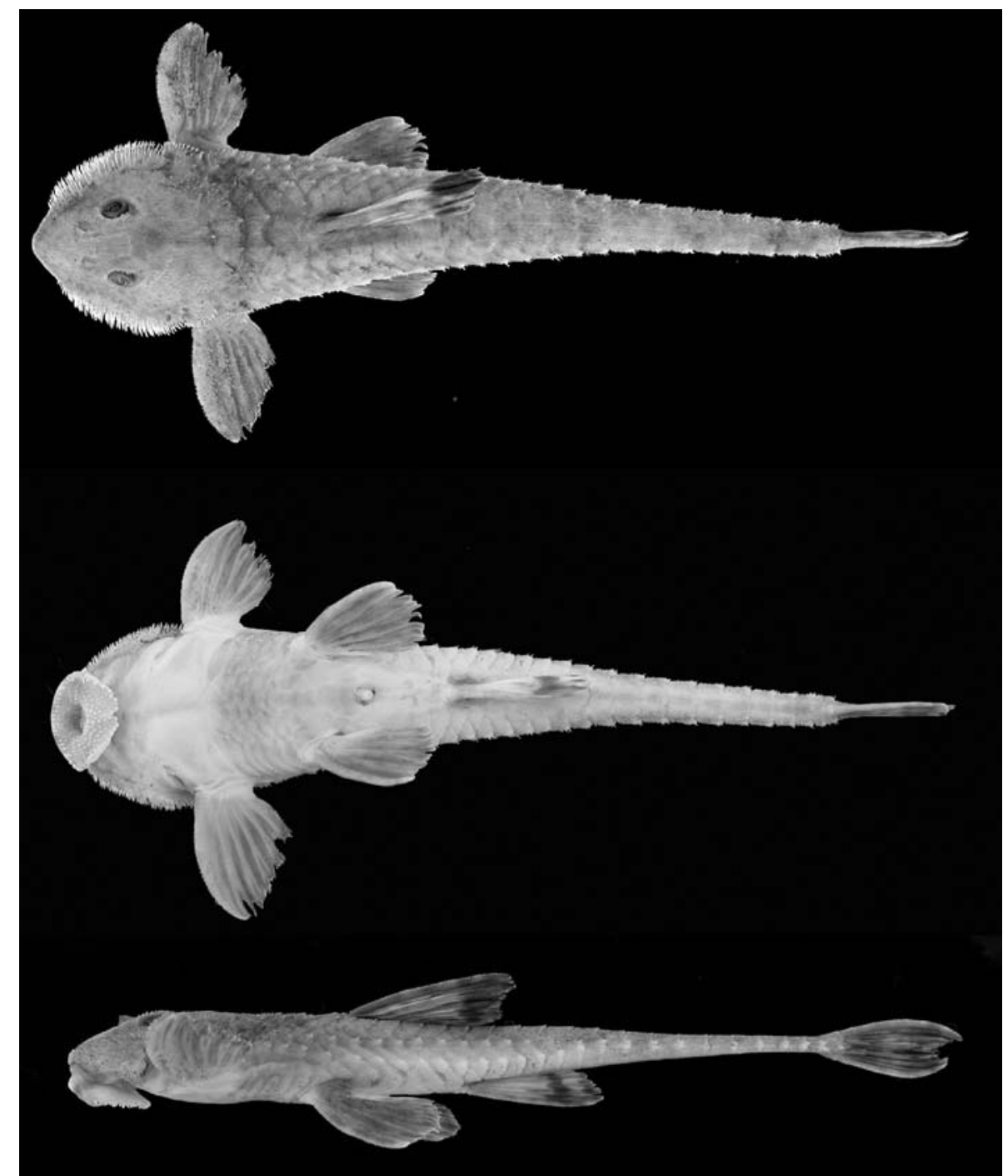

Fig. 4. Rineloricaria anhanguapitan sp. nov. holótipo MCP 21070, ơ, 105,8 mm CP, rio Butiá na Granja Tagliari (afluente do rio Passo Fundo), localidade Entre Rios, Coxilha (28 $5^{\prime}$ 'S $\left.52^{\circ} 28^{\prime} \mathrm{W}\right)$, Rio Grande do Sul. 
estendendo-se anteriormente às órbitas, bifurcada entre as narinas. Par de cristas divergentes do parietosupraoccipital e pré-dorsais suaves. Borda superior da órbita saliente, estendendo-se anteriormente; entalhe pós-orbital com aproximadamente a metade do olho; órbita 1,1 vezes na distância interorbital. Olho arredondado a ovalado, íris parcialmente coberta por um pequeno divertículo.

Lábio inferior bem desenvolvido, coberto com pequenas papilas e margem com franja discreta; duas fileiras de papilas bem visíveis separam o lábio inferior do superior; barbilhão maxilar presente com tamanho aproximado ao do sulco pós-orbital. Dentes afilados e bilobados com as cúspides internas mais longas; 6-9 dentes no pré-maxilar, 7-9 dentes no dentário maiores que os superiores.

Vinte e nove placas na série média (placas laterais da série pós-cleitral). Placas da série média e série médioventral com quilhas ásperas, confluentes, com odontodes conspícuos nas extremidades, coalescendo-se nas últimas 11-13 placas. Linha lateral completa, os poros abrindo-se na série média de placas e estendendo-se até a placa central das placas supracaudais.

Cinco a nove placas abdominais laterais algo alongadas, localizadas entre a inserção do último raio ramificado das nadadeiras peitorais e inserção das nadadeiras pélvicas. Primeira placa abdominal lateral em geral mais larga que as posteriores. Abdome revestido posteriormente pela placa pré-anal bem desenvolvida, margeada anteriormente com três placas. Anteriormente a este complexo 3-5 séries de placas abdominais irregularmente dispostas. Estas séries iniciadas por uma a três placas maiores, geralmente retangulares e alongadas. Placas abdominais nos indivíduos jovens (menos de 50mm CP) não atingem o nível da inserção do último raio ramificado da nadadeira peitoral. Região escapular nua, podendo apresentar uma pequena placa arredondada disposta abaixo da abertura branquial. Dentre os exemplares examinados apenas um (MCP 31781) apresentava uma placa de cada lado da cintura escapular.

Dorsal i+7; raio indiviso menor que comprimento da cabeça. Peitoral i+6; quando adpressa ao corpo, atingindo o primeiro terço da nadadeira pélvica; raios cobertos por odontodes hipertrofiados de pontas curvas nos machos sexualmente maduros. Pélvica i+5; geralmente tocando a inserção da nadadeira anal. Anal i+5. Caudal $\mathrm{i}+10+\mathrm{i}$; raio indiviso superior da nadadeira caudal maior que o raio inferior; borda posterior da nadadeira caudal levemente côncava.

Colorido em álcool. Superfície dorsal castanhoacinzentada. Cabeça e pré-dorsal com pigmentação marmoreada castanho-escura. Cinco faixas castanhoescuras transversais, sendo a primeira na base da nadadeira dorsal e a quinta no final do pedúnculo. Poros do canal sensorial infraorbital geralmente pretos. Raios indivisos das nadadeiras com máculas cinza-escuras. Membranas inter-radiais hialinas a pardacentas. Nadadeira dorsal e anal com membranas inter-radiais fortemente pigmentadas de cinza-escuro, formando uma faixa larga no último terço da nadadeira. Nadadeira caudal com larga faixa distal castanho-acinzentada, não estendida à margem da nadadeira. Superfície ventral amarelada; esbranquiçada na pele nua da cintura escapular.

Distribuição. Afluentes do rio Passo Fundo, alto rio Uruguai.

Etimologia. O nome específico anhaguapitan, substantivo em aposição, foi obtido de uma lenda tupi. A lenda relata um confronto entre Anhaguapitã (o diabo) e São Pedro, no qual o santo teria transformado aves mortas pelo diabo em chuva e pequenas pedras, originando o rio Uruguai.

\section{Rineloricaria zaina sp. nov.} (Figs. 1, 5)

Holótipo, Brasil, Rio Grande do Sul: Independência (rio Buricá, no eixo da barragem da CERTHIL, aprox. $27^{\circ} 51^{\prime} \mathrm{S}$ $\left.54^{\circ} 8^{\prime} \mathrm{W}\right), \sigma^{\circ}, 118,4 \mathrm{~mm}$ CP, 20.XII.1993, J. F. P. Silva \& W. Bruschi Jr. cols. (MCP 19683). Parátipos, Brasil, Rio Grande do Sul: mesmos dados do holótipo, 2 ex., 108-87,2mm CP (MCP 16806); Independência (rio Buricá, abaixo do eixo da Barragem

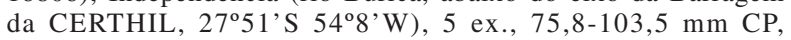
4.IV.1996, W. Bruschi Jr. col. (MCP 18777); Horizontina (afluente do rio Buricá, paralelo à estrada Criciumal-Horizontina, $27^{\circ} 32^{\prime} \mathrm{S}$ $\left.54^{\circ} 15^{\prime} \mathrm{W}\right), 2$ ex., $89,8 \mathrm{~mm} \mathrm{CP}, 8$.VIII.1986, L. Bernardini, G. Bond \& A. Albertini cols. (UFRGS 4335); Três de Maio (arroio Quaraizinho, tributário do rio Buricá, $27^{\circ} 47^{\prime} \mathrm{S} 54^{\circ} 14^{\prime} \mathrm{W}$ ), $77 \mathrm{~mm}$ CP, 12.IV.1994, M. M. Cheffe \& C. J. Maahs cols. (MCP 20562); Giruá (rio Comandaí, estrada Santo Ângelo/Santa Rosa, 28¹0'S $\left.54^{\circ} 18^{\prime} \mathrm{W}\right), 93,6 \mathrm{~mm}$ CP, 22.XII.1985, L. R. Malabarba, R. E. Reis \& S. B. Mallmann cols. (MZUSP 40990); idem, 2 ex., 70$80,9 \mathrm{~mm}$ CP (MCP 10846); Santo Ângelo (segundo rio na estrada de Coimbra para Santo Ângelo, $\left.28^{\circ} 24^{\prime} \mathrm{S} 54^{\circ} 18^{\prime} \mathrm{W}\right), 2$ ex., 20.XII.1985, L. R. Malabarba, R. E. Reis \& S. B. Mallmann cols. (MZUSP 41032); idem, 2 ex., 71,5-112mm CP (MCP 10854); Ijuí (rio Conceição, Barreiro, ponto $\left.1,28^{\circ} 28^{\prime} \mathrm{S} 53^{\circ} 58^{\prime} \mathrm{W}\right), 4$ ex., 102,0-126,7mm CP, 3.XII.1985, C. P. Silva \& M. F. Korndorfer cols. (MCP 10469); Santo Ângelo (rio Piratini na Fazenda Hinz, distrito de Coimbra, $\left.28^{\circ} 42^{\prime} \mathrm{S} 54^{\circ} 25^{\prime} \mathrm{W}\right), 4$ ex., 70,8-94mm CP, 5.I.1985, R. E. Reis \& J. R. Sthemann col. (MAPA 2532); idem localidade anterior, 31 ex., 52,4-121,5mm CP, 19-20.XII.1985, R. E. Reis, L. R. Malabarba \& S. B. Mallmann cols. (MCP 19681). Não parátipos, Brasil, Rio Grande do Sul: Eugênio de Castro (arroio afluente do rio Ijuizinho, $2 \mathrm{~km}$ de Eugênio de Castro em direção a Jóia, $28^{\circ} 33^{\prime} \mathrm{S} 54^{\circ} 7^{\prime} \mathrm{W}$ ), 5 ex., 61,5-70,5mm CP (MCP 16755); Jóia (arroio afluente do rio Ijuizinho na entrada de Jóia

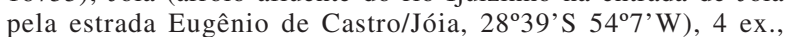
81,5-90,4mm CP (MCP 16780); idem, 15 ex., 63,2-92,3mm CP (MCP 16784); Aratiba (rio Uruguai, a jusante da desembocadura do rio Jacutinga), 2 ex., 93,5-108,1 mm CP (MCN 12464); Marcelino Ramos (rio Teixeira Soares, junto à ponte da RS-491), $72,7 \mathrm{~mm}$ CP (MCN 12525); Mariano Moro (rio Dourado entre Três Barras e Mariano Moro, $\left.27^{\circ} 22^{\prime} \mathrm{S} 52^{\circ} 14^{\prime} \mathrm{W}\right), 130,3 \mathrm{~mm}$ CP (MCP 18551); Nonoai (arroio do Tigre, cerca de $60 \mathrm{~m}$ do rio Passo Fundo, $27^{\circ} 20^{\prime} 6^{\prime \prime S} 52^{\circ} 44^{\prime} 7$ 'W), 5 ex., 59,5-98,5mm CP (MCP 20204); idem, 108,2mm CP (MCP 35008); Marcelino Ramos (rio Uruguai junto à foz do rio Ligeiro, $27^{\circ} 31^{\prime} 28^{\prime \prime} \mathrm{S}$ $51^{\circ} 50$ '15” W), 101,8mm CP (MCP 19340); Nonoai (rio dos Índios, $27^{\circ} 18^{\prime} \mathrm{S} 52^{\circ} 50^{\prime} \mathrm{W}$ ), 2 ex., 91,2-93,4mm CP (MCP 28706); Getúlio Vargas (rio Abaúna, rio Ligeiro, 27 $7^{\circ} 53^{\prime} \mathrm{S} 52^{\circ} 14^{\prime} \mathrm{W}$ ), $110,6 \mathrm{~mm}$ CP (MCP 27025); Tupanciretã (arroio Santana, próximo a Rincão dos Cardoso, rio Jaguari, afluente do rio Ibicuí, $29^{\circ} 14^{\prime} 45^{\prime \prime S} 54^{\circ} 21^{\prime} 10^{\prime \prime} \mathrm{W}$ ), 3 ex., 71,3-117,7mm CP (MCP 27528); Santa Catarina: Itapiranga (arroio Santa Fé, $3 \mathrm{~km}$ a leste de Itapiranga, quase desembocadura com o rio Uruguai, $27^{\circ} 10^{\prime} \mathrm{S} 53^{\circ} 43^{\prime} \mathrm{W}$ ), $81,4 \mathrm{~mm}$ CP (UFRGS 4233); Itá (rio do Engano ou Uvá, estrada entre Itá/Seara, $\left.27^{\circ} 9^{\prime} \mathrm{S} 52^{\circ} 13^{\prime} \mathrm{W}\right), 126,8 \mathrm{~mm}$ CP (MCP 18457); Concórdia (rio Riacho Grande, estrada Piritiba/ $\mathrm{BR} 153,27^{\circ} 21^{\prime} \mathrm{S} 51^{\circ} 57^{\prime} \mathrm{W}$ ), $138,6 \mathrm{~mm}$ CP (MCP 18547); Concórdia (rio Jacutinga na BR283, Seará/Concórdia, 27ำ10'S $52^{\circ} 9^{\prime} \mathrm{W}$ ), 126,7mm CP (MCP 12035); Concórdia (rio do Peixe em Volta Grande, $27^{\circ} 28^{\prime}$ 'S 51 $53^{\circ} \mathrm{W}$ ), 115,3mm CP (MCP 12271); Concórdia (rio Rancho Grande), 4 ex. (MCN 12496); Ipira (rio Lajeado 37 Passos, estrada Alto Bela Vista/Ipira), 2 ex. (MCN 
12865); Arabutã (rio Jacutinga a montante da ponte SC465), 76,1mm CP (MCN 12817).

Diagnose. Rineloricaria zaina se distingüe das demais espécies do gênero pela seguinte combinação de caracteres: ponta do focinho com uma área nua ovalada não se estendendo posteriormente; cristas dorsais e da cabeça inconspícuas; abdome completamente coberto por 5-6 séries de placas pequenas e uniformes, precedidas por placas menores e numerosas na região da cintura escapular; placa pré-anal grande; nadadeiras peitorais atingindo o primeiro terço das pélvicas; pélvicas ultrapassando a origem da nadadeira anal; faixa escura na margem posterior da nadadeira caudal. Esta espécie assemelha-se a $R$. jaraguensis pelo abdome coberto de placas, mas diferencia-se facilmente desta pelo menor tamanho da cabeça $(22,4-24,8 \%$ vs. $25,9-26,6 \%$ no CP); diferencia-se de $R$. thrissoceps (também com abdome coberto) pela maior distância interorbital $(22,1-26,6 \% \mathrm{vs}$. $19,8 \%$ no CC); $R$. quadrensis, $R$. felipponei, $R$. steindachneri e $R$. henselli diferenciam-se de $R$. zaina pelas mesmas características que $R$. anitae (ver diagnose). Rineloricaria zaina tem o formato da cabeça ovalado a arredondado $v s$. o formato quase triangular de $R$. microlepidogaster; excluindo o comprimento das nadadeiras, diferencia-se desta espécie pelas mesmas características que $R$. anitae (ver diagnose).
Descrição. Dados morfométricos apresentados na Tabela III. Corpo achatado, fortemente deprimido no pedúnculo caudal, afilando-se posteriormente a partir das nadadeiras peitorais. Perfil dorsal levemente convexo da ponta do focinho à inserção da nadadeira dorsal, declinando levemente até tornar-se reto no final do pedúnculo caudal.

Perfil anterior da cabeça em vista dorsal ovalado a aproximadamente triangular. Odontodes pequenos, todavia proeminentes nas laterais da cabeça dos machos sexualmente maduros. Ponta do focinho com área nua ovalada não alcançando o poro mais anterior do canal sensorial infraorbital na margem inferior do focinho. Crista inconspícua originada na ponta do focinho, bifurcandose entre as narinas. Par de cristas divergentes do parietosupraoccipital e pré-dorsais suaves. Borda superior da órbita baixa; entalhe pós-orbital pequeno; órbita 1,2 vezes na distância interorbital. Olho arredondado a ovalado, íris parcialmente coberta por um pequeno divertículo.

Lábio inferior bem desenvolvido, coberto com pequenas papilas e margem com franja discreta; duas fileiras de papilas bem visíveis separam o lábio inferior do superior; barbilhão maxilar presente com tamanho aproximado ao do sulco pós-orbital. Dentes afilados e bilobados com as cúspides internas mais longas; 6-9 dentes no pré-maxilar, 5-9 dentes no dentário maiores que os superiores.

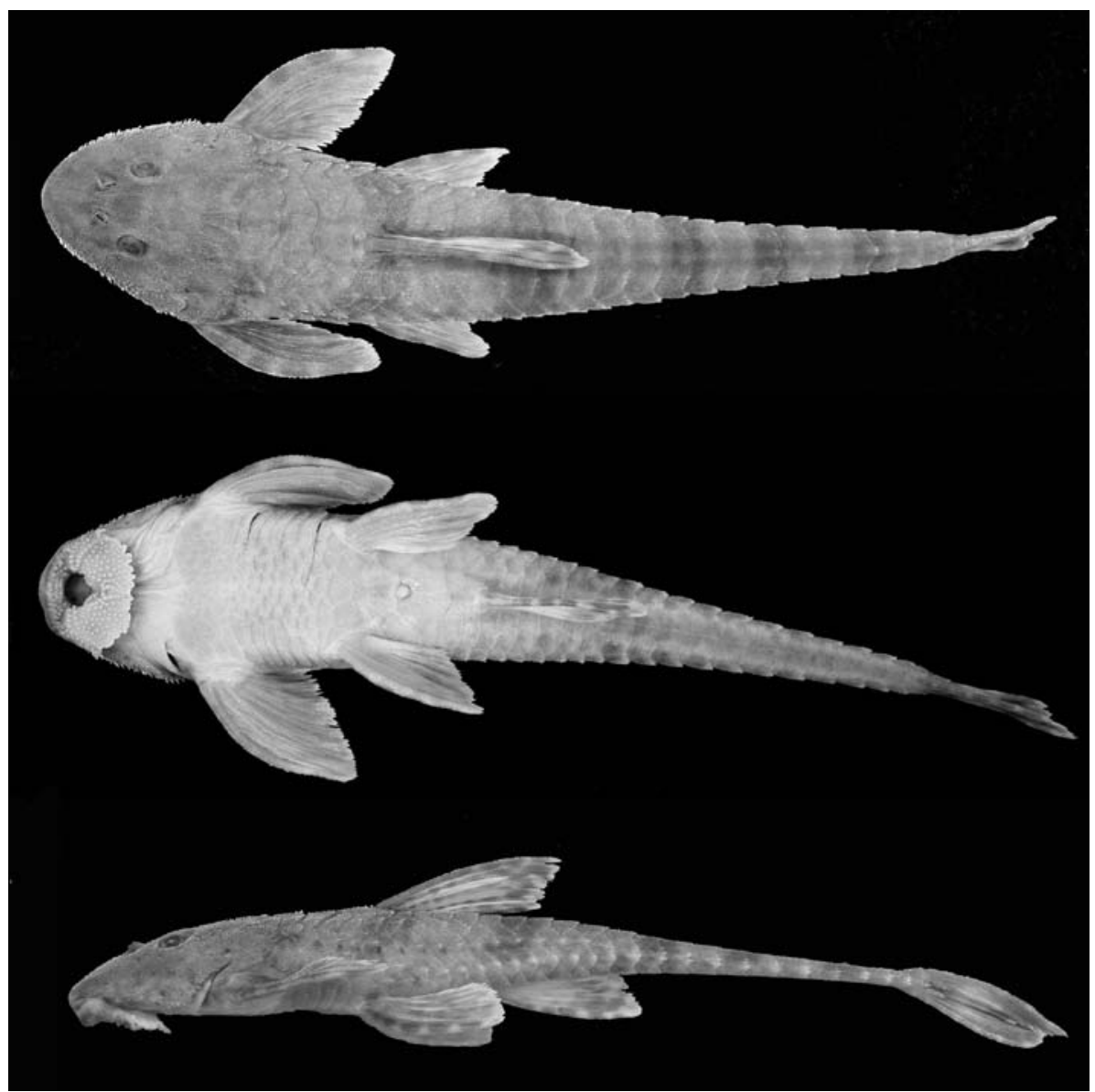

Fig. 5. Rineloricaria zaina sp. nov. holótipo MCP 19683, ơ, 118,4 mm CP, rio Buricá, no eixo da barragem da CERTHIL, Independência (275ำ $\left.54^{\circ} 8^{\prime} \mathrm{W}\right)$, Rio Grande do Sul. 
Vinte e nove placas na série média (placas laterais da série pós-cleitral). Placas da série média e série médioventral com quilhas ásperas, confluentes, com odontodes conspícuos nas extremidades, coalescendo-se nas últimas 10-14 placas. Linha lateral completa, os poros abrindo-se na série média de placas e estendendo-se até a placa central das placas supracaudais.

Cinco a nove placas abdominais laterais, localizadas entre o último raio ramificado das nadadeiras peitorais e inserção das nadadeiras pélvicas. Abdome revestido posteriormente pela placa pré-anal bem desenvolvida, anteriormente margeada com três placas, algumas vezes divididas, aumentando seu número. Anteriormente a este complexo, 5-6 séries de placas pequenas. Região escapular revestida de placas menores que as abdominais e bastante numerosas.

Dorsal i+7; raio indiviso menor que comprimento da cabeça. Peitoral i+6; quando adpressa ao corpo, atingindo o primeiro terço da nadadeira pélvica. Pélvica i+5, ultrapassando a inserção da nadadeira anal. Anal $\mathrm{i}+5$. Caudal $\mathrm{i}+10+\mathrm{i}$; raio indiviso superior da nadadeira caudal maior que o raio inferior; borda posterior da nadadeira caudal levemente côncava.

Colorido em álcool. Superfície dorsal castanhoacinzentada, castanho-escura ou castanho-avermelhada; mais escura na cabeça e numa faixa difusa na região occipital. Lateral da cabeça com manchas escuras de forma e padrão irregular. Cinco faixas castanho-escuras transversais, sendo a primeira na base da nadadeira dorsal e a quinta no final do pedúnculo. Raios indivisos das nadadeiras com máculas cinza-escuras. Pontuações nos raios indivisos da nadadeira dorsal formando estrias irregulares. Membranas inter-radiais distais das nadadeiras peitorais com coloração alaranjada a castanha em estrias transversais. Base da nadadeira caudal escurecida; margem distal da nadadeira com faixa alargada castanho-escura. Superfície ventral amarelada; alguns exemplares com pigmentação escura no pedúnculo caudal.

Distribuição. Afluentes do rio Uruguai desde Marcelino Ramos (RS) e/ou rio do Peixe (SC) ao rio Jaguari (afluente do rio Ibicuí).

Etimologia. Zaina é o nome dado à pelagem negra ou castanho-escura, com pouco brilho, de cavalos ou bovinos. O nome específico zaina, um adjetivo, é empregado em alusão à cor castanho-escura de vários indivíduos da espécie e ao aspecto fosco e aveludado, dado pelo pequeno tamanho dos odontodes.

\section{Rineloricaria capitonia sp. nov. (Figs. 1, 6-7)}

Holótipo, Brasil, Rio Grande do Sul: Condor (rio Alegre,

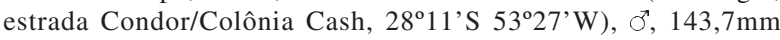
CP, 23.III.1996, J. F. P. Silva \& W. Bruschi Jr. cols. (MCP 19687). Parátipos, Brasil, Rio Grande do Sul: mesmos dados do holótipo, 8 ex., 110,1-130,6mm CP (MCP 18740); Condor (rio Alegre junto ao eixo da futura barragem da Hidropan, $28^{\circ} 11^{\prime} \mathrm{S} 51^{\circ} 27^{\prime} \mathrm{W}$ ), 24 ex., 53,1-145,9mm CP, 23.III.1996, J. F. P. Silva \& W. Bruschi Jr. cols. (MCP 18739); Condor (rio Alegre, no limite dos municípios de Condor e Panambi), 4 ex., 70,1-100,4mm CP, 17.XII.1994, W. R. Koch col. (MCN 11846); Panambi (rio Palmeira, no lago do reservatório da $\mathrm{PCH}$ rio Palmeira, $28^{\circ} 14^{\prime} \mathrm{S}$ $\left.53^{\circ} 33^{\prime} \mathrm{W}\right), 8$ ex., 136, 3-170,6mm CP, 3.XI.2002, J. F. P. Silva
\& J. Anza cols. (MCP 31717); Condor (rio Morimotimã ou Divisa a montante da cachoeira, $\left.28^{\circ} 12^{\prime} \mathrm{S} 53^{\circ} 31^{\prime} \mathrm{W}\right), 3$ ex., 143,3191,7mm CP, 29.VII.1997, J. F. P. Silva \& W. Bruschi Jr. cols. (MCP 19911); Panambi (rio Palmeira, $28^{\circ} 17^{\prime} \mathrm{S} 53^{\circ} 30^{\prime} \mathrm{W}$ ), 5 ex., 90,4-144,5mm CP, 05.I.1999, W. Bruschi Jr. \& A. Cunha cols. (MCP 26900). Não parátipos, Brasil, Rio Grande do Sul: Entre Rios do Sul (barragem do rio Passo Fundo, $27^{\circ} 40^{\prime} \mathrm{S} 52^{\prime} 45^{\circ} \mathrm{W}$ ), $111 \mathrm{~mm}$ CP (MCP 8339); Ijuí (rio Potiribu, Parque Assis Brasil, ponto $\left.2,28^{\circ} 23^{\prime} \mathrm{S} 53^{\circ} 55^{\prime} \mathrm{W}\right), 134 \mathrm{~mm} \mathrm{CP}$ (MCP 11705).

Diagnose. Rineloricaria capitonia se distingüe das demais espécies do gênero pelo abdome coberto parcialmente por placas, com três placas grandes precedendo a placa pré-anal, anteriormente duas a três séries de placas elipsoidais - não atingindo a altura da inserção das peitorais - e um conjunto de pequenas placas localizadas abaixo das aberturas branquiais, não contatando as placas abdominais laterais. Em acréscimo, a seguinte combinação ajuda a diferenciá-la das outras espécies: ponta do focinho com área nua estendida posteriormente alcançando o poro mais anterior do canal sensorial infraorbital, nadadeiras peitorais atingindo o primeiro terço das pélvicas e uma faixa escura na margem distal da nadadeira caudal. Entre as espécies simpátricas assemelha-se pelo padrão de placas abdominais a $R$. reisi sp. nov., da qual diferencia-se pela maior distância interorbital (21,5-25,6\% vs. 17-19,9\% no CC). Rineloricaria capitonia assemelha-se a $R$. misionera pela região escapular sem placas, mas diferencia-se desta pela área nua do focinho estendida posteriormente ( $v s$. não estendida).

Descrição. Dados morfométricos apresentados na Tabela III. Corpo achatado, fortemente deprimido no pedúnculo caudal, afilando-se posteriormente a partir das nadadeiras peitorais. Perfil dorsal levemente convexo da ponta do focinho à inserção da nadadeira dorsal, declinando levemente até tornar-se reto no final do pedúnculo caudal.

Cabeça grande, perfil anterior em vista dorsal triangular. Odontodes pequenos, cristas da cabeça, supraoccipitais e pré-dorsais suaves e inconspícuas. Odontodes proeminentes nas laterais da cabeça dos machos sexualmente maduros. Ponta do focinho com área nua estendida posteriormente, alcançando o poro mais anterior do canal sensorial infraorbital na margem inferior do focinho. Borda superior da órbita baixa; entalhe pósorbital aproximadamente a metade do olho; órbita 1,1 vezes na distância interorbital. Olho arredondado a ovalado, íris parcialmente coberta por um pequeno divertículo.

Lábio inferior bem desenvolvido, coberto com pequenas papilas e margem com franja discreta; duas fileiras de papilas bem visíveis separam o lábio inferior do superior; barbilhão maxilar presente com tamanho aproximado ao do sulco pós-orbital. Dentes afilados e bilobados com as cúspides internas mais longas; 6-11 dentes no pré-maxilar, 5-10 dentes no dentário maiores que os superiores.

Vinte e nove placas na série média (placas laterais da série pós-cleitral). Placas da série média e série médioventral com quilhas ásperas, confluentes, com odontodes conspícuos nas extremidades, coalescendo-se nas últimas 8-12 placas. Linha lateral completa, os poros 
abrindo-se na série média de placas e estendendo-se até a placa central das placas supracaudais.

Cinco a oito placas abdominais laterais alongadas, localizadas entre a inserção do último raio ramificado das nadadeiras peitorais e inserção das nadadeiras pélvicas. Primeira placa abdominal lateral em geral mais larga e mais curta que as posteriores. Abdome revestido posteriormente pela placa pré-anal bem desenvolvida, margeada por três placas poligonais. Complexo pré-anal antecedido por três a cinco placas. Antecedendo este conjunto posterior, o abdome pode ser inteiramente nu ou com uma a três séries irregulares de placas, aproximadamente elipsóides, não contatando as placas abdominais laterais mais anteriores. Pequenas placas formando um conjunto justamente posterior às aberturas branquiais, não tocando as placas abdominais laterais.

Dorsal i+7; raio indiviso menor que comprimento da cabeça. Peitoral i+6; quando adpressa ao corpo, atingindo o primeiro terço da nadadeira pélvica. Pélvica i+5, atingindo a inserção da nadadeira anal ou estendendo- se pouco além. Anal i+5. Caudal i+10+i; raio indiviso superior da nadadeira caudal maior que o raio inferior; borda posterior da nadadeira caudal levemente côncava.

Colorido em álcool. Superfície dorsal castanho-clara, levemente mais escura na região occipital. Cinco faixas transversais castanhas, pouco evidentes, sendo a primeira na base da nadadeira dorsal e a quinta no final do pedúnculo. Raios indivisos das nadadeiras com pontuações acinzentadas. Ápice da nadadeira dorsal de coloração acinzentada; pontuações nos raios indivisos formando estrias irregulares. Nadadeiras peitorais com coloração alaranjada a castanha formando estrias transversais. Nadadeira caudal escurecida na base; margem distal com faixa acinzentada uniforme. Superfície ventral amarelada.

Distribuição. Rio Alegre e rio Palmeira (afluentes do rio Ijuí) e rio Passo Fundo.

Etimologia. O nome específico capitonia é um adjetivo de origem latina, significando "com cabeça grande".

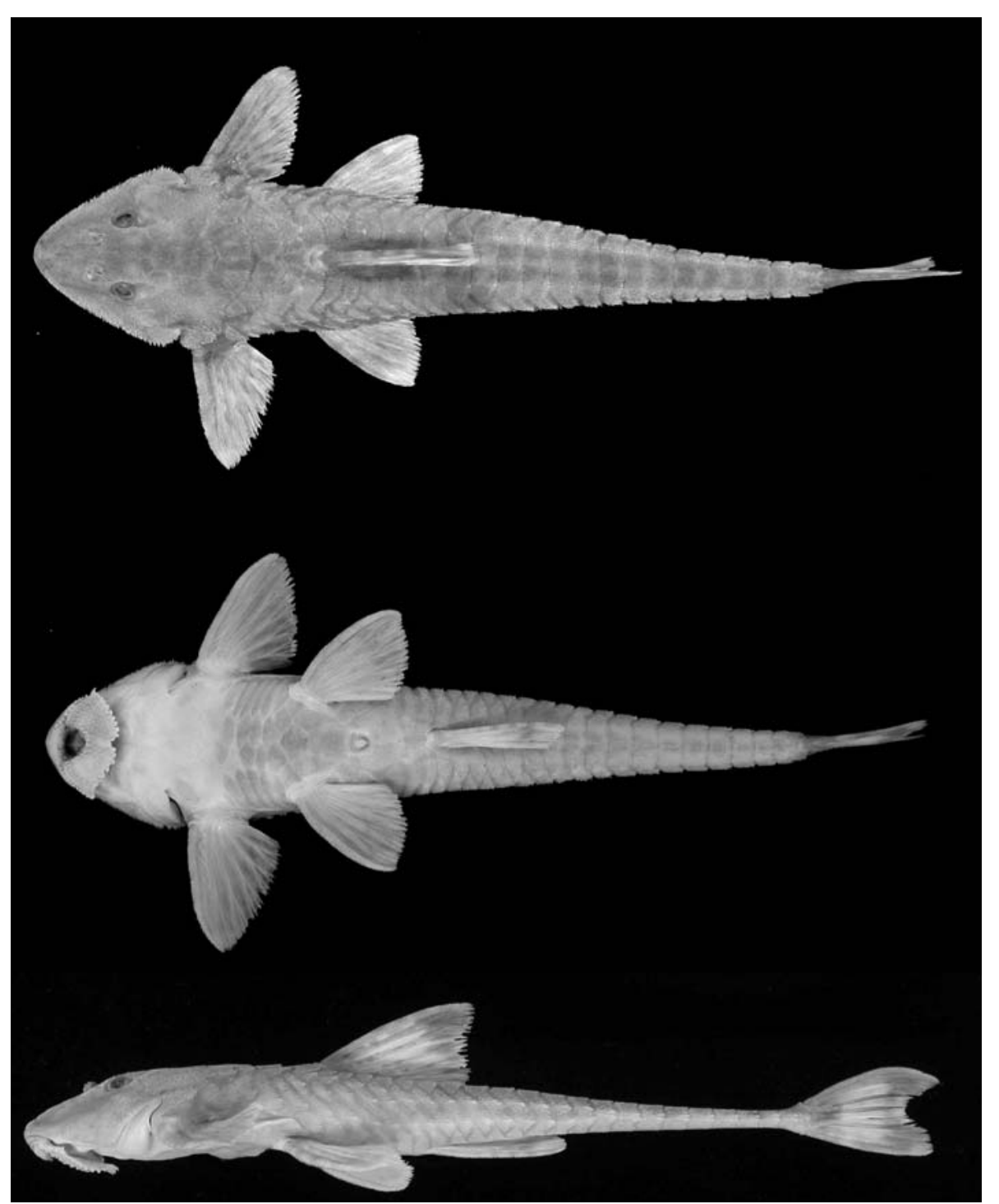

Fig. 6. Rineloricaria capitonia sp. nov. holótipo MCP 19687, ơ, 143,7mm CP, rio Alegre, estrada Condor/Colônia Cash, Condor (28 $11^{\prime}$ 'S $\left.53^{\circ} 27^{\prime} \mathrm{W}\right)$, Rio Grande do Sul. 
Tabela III. Dados morfométricos do holótipo e parátipos de Rineloricaria zaina, R. capitonia e R. stellata (n, número de exemplares excluíndo holótipo).

\begin{tabular}{|c|c|c|c|c|c|c|c|c|c|c|c|c|}
\hline \multirow[b]{4}{*}{ Comprimento padrão $(\mathrm{mm})$} & \multicolumn{4}{|c|}{ R. zaina } & \multicolumn{4}{|c|}{ R. capitonia } & \multicolumn{4}{|c|}{ R. stellata } \\
\hline & \multirow[t]{2}{*}{ holótipo } & \multicolumn{3}{|c|}{ parátipos } & \multicolumn{2}{|c|}{ holótipo } & \multicolumn{2}{|l|}{ parátipos } & \multirow[t]{2}{*}{ holótipo } & \multicolumn{3}{|c|}{ parátipos } \\
\hline & & $\mathrm{n}$ & variação & média & & $\mathrm{n}$ & variação & média & & $\mathrm{n}$ & variação & média \\
\hline & 108,0 & 43 & $52,4-126,7$ & 86,4 & 143,7 & 22 & $53,1-145,9$ & 102,4 & 90 & 21 & $52,2-100,5$ & 82,8 \\
\hline Comprimento da cabeça & 23,4 & 43 & $22,4-24,8$ & 23,6 & 27,0 & 22 & $24,1-27,6$ & 25,6 & 23,0 & 21 & $21,7-24,5$ & 22,8 \\
\hline Largura cleitral & 20,5 & 43 & $16,2-21,6$ & 19,5 & 22,6 & 22 & $18,3-22,6$ & 20,5 & 19,4 & 21 & $16,6-19,9$ & 18,4 \\
\hline Comprimento pré-dorsal & 34,4 & 43 & $32,6-36,9$ & 34,7 & 38,0 & 22 & $34,5-39,5$ & 36,8 & 35,1 & 21 & $31,1-35,7$ & 33,3 \\
\hline $\begin{array}{l}\text { Comprimento raio } \\
\text { indiviso da dorsal }\end{array}$ & 19,9 & 42 & $18,9-23,4$ & 20,7 & 20,7 & 22 & $19,6-22,8$ & 21,4 & 23,1 & 20 & $13,8-23,6$ & 20,8 \\
\hline $\begin{array}{l}\text { Comprimento raio } \\
\text { indiviso da anal }\end{array}$ & 16,9 & 38 & $16,1-19,8$ & 18,0 & 16,6 & 21 & $15,8-18,9$ & 17,4 & 19,1 & 20 & $16,3-20,8$ & 18,0 \\
\hline $\begin{array}{l}\text { Comp. raio } \\
\text { indiviso da peitoral }\end{array}$ & 19,5 & 43 & $17,5-20,6$ & 19,3 & 18,4 & 22 & $16,5-18,9$ & 17,9 & 17,4 & 21 & $15,5-18,7$ & 17,0 \\
\hline $\begin{array}{l}\text { Comprimento raio } \\
\text { indiviso da pélvica }\end{array}$ & 16,3 & 43 & $15,8-19,2$ & 17,5 & 16,7 & 22 & $14,1-18,0$ & 16,7 & 16,7 & 21 & $14,3-18,4$ & 15,7 \\
\hline $\begin{array}{l}\text { Comprimento raio indiviso } \\
\text { superior caudal }\end{array}$ & 16,3 & 39 & $15,3-20,1$ & 16,9 & 17,1 & 19 & $15,7-18,2$ & 17,4 & & 15 & $13,8-21,3$ & 17,7 \\
\hline $\begin{array}{l}\text { Comprimento raio indiviso } \\
\text { inferior caudal }\end{array}$ & 14,2 & 42 & $12,9-16,3$ & 14,7 & 16,1 & 21 & $13,5-16,2$ & 15,0 & & 16 & $12,7-17,2$ & 14,7 \\
\hline Comprimento torácico & 14,6 & 43 & $12,9-17,5$ & 14,5 & 13,6 & 22 & $12,1-15,0$ & 13,6 & 17,1 & 21 & $12,9-16,8$ & 14,8 \\
\hline Comprimento abdominal & 16,1 & 43 & $14,3-19,0$ & 16,8 & 18,6 & 22 & $15,4-19,8$ & 17,8 & 15,8 & 21 & $14,1-17,7$ & 16,4 \\
\hline Comprimento pós-dorsal & 55,1 & 43 & $52,7-58,7$ & 56,0 & 50,1 & 22 & $49,1-56,1$ & 52,8 & 56,1 & 21 & $52,0-59,3$ & 56,4 \\
\hline Comprimento pedúnculo caudal & 54,0 & 43 & $51,0-56,3$ & 53,4 & 47,8 & 22 & $47,7-54,8$ & 51,1 & 54,4 & 21 & $50,4-57,2$ & 54,2 \\
\hline Altura corpo nadadeira dorsal & 10,8 & 43 & $8,6-13,0$ & 10,8 & 11,3 & 22 & $9,4-12,6$ & 10,9 & 10,0 & 21 & $9,4-13,0$ & 10,9 \\
\hline $\begin{array}{l}\text { Largura corpo nadadeira anal } \\
\text { Comprimento da cabeça }(\%)\end{array}$ & 13,0 & 43 & $10,2-13,7$ & 12,1 & 13,2 & 22 & $9,8-13,4$ & 12,4 & 12,9 & 21 & $10,2-13,1$ & 11,9 \\
\hline Altura da cabeça & 43,9 & 43 & $39,5-48,8$ & 43,8 & 41,8 & 22 & $39,9-45,7$ & 42,3 & 47,8 & 21 & $39,0-47,5$ & 44,0 \\
\hline Comprimento do focinho & 50,6 & 43 & $49,4-55,5$ & 52,3 & 50,3 & 22 & $47,1-51,5$ & 49,8 & 49,3 & 21 & $45,1-50,0$ & 47,5 \\
\hline Diâmetro orbital & 19,8 & 43 & $17,2-23,5$ & 20,0 & 22,2 & 22 & $21,1-24,0$ & 22,1 & 22,1 & 21 & $20,7-24,4$ & 22,8 \\
\hline Distância interorbital & 23,7 & 43 & $22,1-26,6$ & 24,4 & 22,7 & 22 & $21,5-25,6$ & 23,5 & 23,7 & 21 & $22,7-26,2$ & 24,6 \\
\hline
\end{tabular}
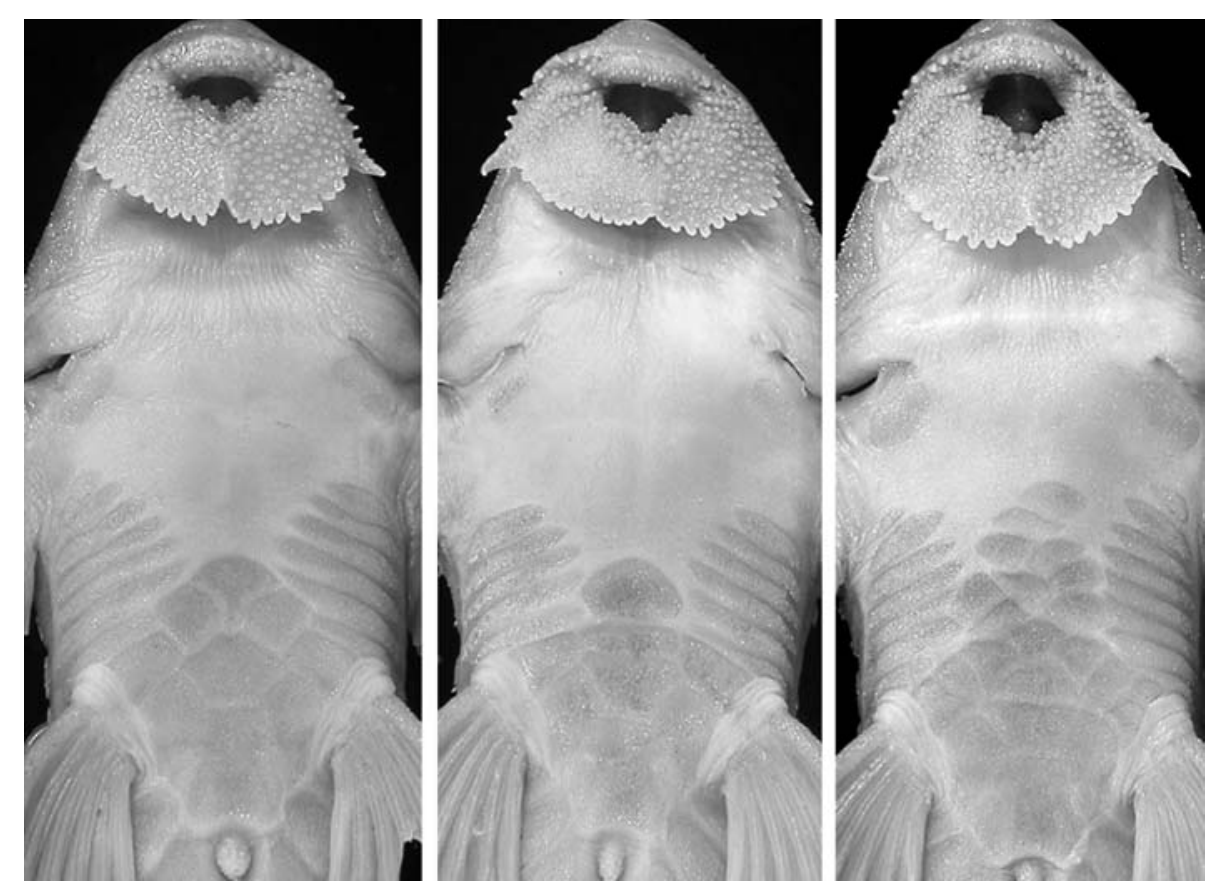

Fig. 7. Rineloricaria capitonia sp. nov. parátipos MCP 18740. Variação das placas abdominais.

\section{Rineloricaria stellata sp. nov.}

(Figs. 1, 8)

Holótipo, Brasil, Rio Grande do Sul: Ijuí (arroio afluente do rio Ijuí, estrada de São Luiz Gonzaga/Ijuí, 28 23'S 5355'W), o, 90mm CP, 19.XI.1984, L. R. Malabarba \& R. E. Reis cols.
(MCP 19682). Parátipos, Brasil, Rio Grande do Sul: mesmos dados do holótipo, 2 ex., 52,2-83,8mm CP (MCP 10160); mesma localidade e data de coleta do holótipo, 10 ex., 54,5-98,7mm CP, R. E. Reis \& L. R. Malabarba cols. (MAPA 2455); Santo Ângelo

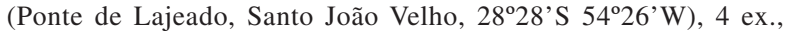
82,9-94,5mm CP, 19.II.1982 (UFRGS 2823); Três de Maio 
(arroio Quaraizinho, tributário do rio Buricá, $27^{\circ} 47^{\prime} \mathrm{S} 54^{\circ} 14^{\prime} \mathrm{W}$ ), 15 ex., 41,9-84,8mm CP, 12.IV.1994, M. M. Cheffe \& C. J. Maahs cols. (MCP 17545); São Luiz Gonzaga (arroio Ximbocuzinho, na estrada RS168, a cerca de $4 \mathrm{~km}$ de São Luiz Gonzaga, 28 27'3"S 5457'31”W), 9 ex., 3 medidos, 77 100,5mm CP, 7.IV.1999, W. A. Santos, J. F. P. Silva \& V. A. Bertaco col. (MCP 22842); Salvador das Missões (arroio Pobre, na estrada para Cerro Largo, afluente do Ijuí, 28 7'15"S 5450'57"), 4 ex., 2 medidos, 79,0-94,8mm CP, 29.II.2004, A. R. Cardoso \& V. A. Bertaco cols. (MCP 34921). Não parátipos, Brasil, Rio Grande do Sul: Santo Ângelo (rio Piratini na Fazenda Hinz, distrito de Coimbra, 28 $\left.8^{\circ} 42^{\prime} \mathrm{S} 54^{\circ} 25^{\prime} \mathrm{W}\right), 2$ ex., 86,5-96,8mm CP (MAPA 2539); Santo Ângelo (rio Piratini, distrito de Coimbra, 2839'S 5431'W), 2 ex., 88,9-89,8mm CP (UFRGS 2979); arroio limite entre Santo Antônio das Missões e Boçoroca, estrada de São Borja, 84,3mm CP (MAPA 2471); Santo Antônio das Missões (arroio Passo do Rosário ou Passo da Cancela, estrada São Nicolau/ Garruchos, 28 $8^{\circ} 13^{\prime} \mathrm{S} 55^{\circ} 30^{\prime} \mathrm{W}$ ), 64,5mm CP (MCP 12701); São Luiz Gonzaga (arroio Ximbocuzinho, na estrada São Luiz Gonzaga/ Boçoroca, 4 quilômetros da entrada de São Luiz Gonzaga, 28²7'S 5458'W), 86mm CP (MCP 16193); Entre-Ijuís (arroio Lajeado do Moinho, afluente do rio Ijuizinho, a 7 quilômetros a SW de Entre-Ijuís, $\left.28^{\circ} 27^{\prime} \mathrm{S} 54^{\circ} 22^{\prime} \mathrm{W}\right), 5 \mathrm{ex}, 1$ medido, 72,7mm CP (MCP 16767); São Francisco de Assis (rio Inhacunda em São Francisco de Assis na saída para Manoel Viana, 29³2'51's 558'11'W), 2 ex., 94,5-109,5mm CP (MCP 23107).
Diagnose. Rineloricaria stellata se distingüe das demais espécies do gênero Rineloricaria pela combinação da ponta do focinho com área nua estendida posteriormente alcançando o poro mais anterior do canal sensorial infraorbital ou além deste; abdome completamente coberto por três a cinco séries de placas; nadadeiras peitorais atingindo pouco além da inserção das nadadeiras pélvicas; filamento no raio superior da nadadeira caudal. Rineloricaria stellata assemelha-se a $R$. nigricauda (Regan, 1904) pelo filamento da caudal e pela área nua no focinho, mas diferencia-se por não apresentar na região posterior da nadadeira caudal uma listra escura alargada característica desta espécie; distingue-se de $R$. longicauda pela largura do corpo no primeiro raio da anal (4,5-6 vs. 5,4-9,8 vezes no comprimento do pedúnculo caudal) e pelo filamento da nadadeira caudal ausente em $R$. longicauda; assemelhase a $R$. cadeae na área nua do focinho, mas diferencia-se desta principalmente por apresentar 3-5 vs. três séries de placas abdominais e pela maior distância interorbital (22,7$26,2 \%$ vs. $22,9 \%$ no CC); diferencia-se de $R$. pareicantha (Fowler, 1943) pela maior altura do corpo ao nível da

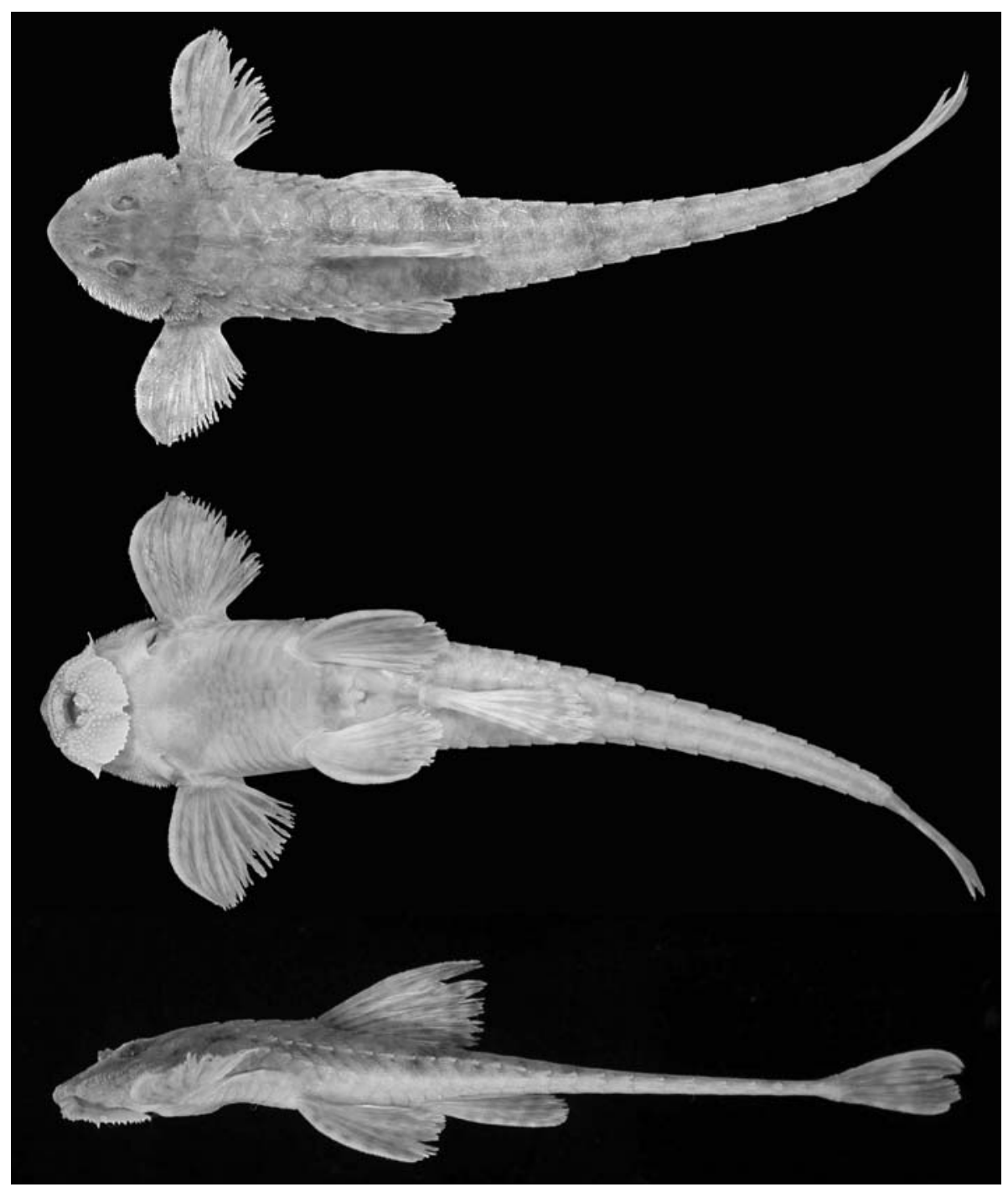

Fig. 8. Rineloricaria stellata sp. nov. holótipo MCP 19682, ơ, 90mm CP, arroio afluente do rio Ijuí, estrada de São Luiz Gonzaga/Ijuí, Ijuí $\left(28^{\circ} 23^{\prime} \mathrm{S} 53^{\circ} 55^{\prime} \mathrm{W}\right)$, Rio Grande do Sul. 
nadadeira dorsal (9,4-13\% vs. $9 \%$ no CP) e pelo maior comprimento das nadadeiras peitorais que atingem além da base das nadadeiras pélvicas vs. nadadeiras peitorais atingindo a base das pélvicas; diferencia-se de $R$. pentamaculata Langeni \& Araújo, 1994 pelo menor comprimento da nadadeira dorsal $(4,2-5,1 \mathrm{vs}$. 5-5,6 vezes no CC). Contrariamente, $R$. stellata tem as nadadeiras peitorais e pélvicas estendendo-se respectivamente além da base das nadadeiras pélvica e anal, sendo que em $R$. pentamaculata estas nadadeiras atingem a base das nadadeiras adjacentes.

Descrição. Dados morfométricos apresentados na Tabela III. Corpo achatado, fortemente deprimido no pedúnculo caudal, afilando-se posteriormente a partir das nadadeiras peitorais. Perfil dorsal levemente convexo da ponta do focinho à inserção da nadadeira dorsal, declinando levemente até tornar-se reto no final do pedúnculo caudal.

Perfil anterior da cabeça em vista dorsal triangular. Odontodes conspícuos na cabeça e região pré-dorsal, dispostos em linhas definidas sobre o pterótico composto; desenvolvidos nas laterais da cabeça dos machos sexualmente maduros. Ponta do focinho com área nua de comprimento variável, estendendo-se posteriormente, alcançando (ou ultrapassando) o poro mais anterior do canal sensorial infraorbital na margem inferior do focinho. Crista originada na ponta do focinho, bifurcada na região interorbital. Par de cristas divergentes do parieto-supraoccipital e pré-dorsais conspícuas. Borda superior da órbita saliente, estendendo-se anteriormente; entalhe pós-orbital com aproximadamente a metade do olho ou pouco maior; órbita 1,1 vezes na distância interorbital. Olho arredondado a ovalado, íris parcialmente coberta por um pequeno divertículo.

Lábio inferior bem desenvolvido, coberto com pequenas papilas e margem com franja discreta; duas fileiras de papilas bem visíveis separam o lábio inferior do superior; barbilhão maxilar presente com tamanho aproximado ao do sulco pós-orbital. Dentes afilados e bilobados com as cúspides internas mais longas; 6-11 dentes no pré-maxilar, 5-10 dentes no dentário maiores que os superiores.

Vinte e nove placas na série média (placas laterais da série pós-cleitral). Placas da série média e série médioventral com quilhas ásperas, confluentes, com odontodes conspícuos nas extremidades, coalescendo-se nas últimas 11-14 placas. Linha lateral completa, os poros abrindo-se na série média de placas e estendendo-se até a placa central das placas supracaudais.

Cinco a oito placas abdominais laterais, localizadas entre a base das nadadeiras peitorais e inserção das nadadeiras pélvicas. Abdome totalmente revestido de placas. Pré-anal margeada por três placas, precedidas por outras cinco a sete comparativamente menores. Anterior a este complexo, três a cinco séries irregulares de placas pequenas. Um conjunto de placas ainda menores dispostas desordenadamente reveste a região da cintura escapular, podendo apresentar falhas na cobertura em alguns indivíduos.

Dorsal i+7; raio indiviso menor ou quase igual ao comprimento da cabeça. Peitoral i+6; quando adpressa ao corpo, atingindo pouco além da inserção da nadadeira pélvica; raios cobertos por odontodes hipertrofiados de pontas curvas nos machos sexualmente maduros. Pélvica $i+5$, tocando a inserção da nadadeira anal ou indo pouco além desta. Anal i+5. Caudal i+10+i; raio indiviso superior da nadadeira caudal com filamento curto; borda posterior da nadadeira caudal levemente côncava.

Colorido em álcool. Superfície dorsal castanhoacinzentada, mais escura na cabeça e numa faixa difusa na região occipital. Lateral da cabeça com pigmentação acinzentada formando padrão marmoreado. Poros do canal sensorial infraorbital e da linha lateral pretos. Cinco faixas castanho-escuras transversais, sendo a primeira na base da nadadeira dorsal e a quinta no final do pedúnculo. Raios das nadadeiras pares e dorsal com pontuações conspícuas cinza-escuras ou pretas formando estrias oblíquas. Membranas inter-radiais hialinas. Nadadeira caudal igualmente estriada, sendo este padrão acentuado distalmente. Superfície ventral amarelada.

Distribuição. Afluentes dos rios Buricá, Ijuí, Piratini e Ibicuí, tributários do rio Uruguai.

Etimologia. O nome específico stellata, adjetivo de origem latina significando "estrelada", dado à espécie em alusão às pontuações escuras evidentes nas nadadeiras e nos poros da linha lateral.

\section{Rineloricaria reisi sp.nov.}

(Figs. 1, 9)

Holótipo, Brasil, Rio Grande do Sul: Santo Ângelo (rio Piratini na Fazenda Hinz, distrito de Coimbra, $28^{\circ} 42^{\prime} \mathrm{S} 54^{\circ} 25^{\prime} \mathrm{W}$ ), o, $168 \mathrm{~mm}$ CP, 4.I.1985, R. E. Reis \& J. R. Stehmann cols. (MZUSP 28748). Parátipos, Brasil, Rio Grande do Sul: mesmos dados do holótipo, 95,1 mm CP (MCP 10292); idem, 95,5mm CP (MCP 10293); idem, 153,8mm CP (MAPA 2519); mesma localidade do holótipo, 197,7mm CP, 16.II.1982, L. R. Malabarba \& J. R. Stehmann cols. (ZMA 119408); mesma localidade do holótipo, 7 ex., 122,9-164,4mm CP, 19-20.XII.1985, R. E. Reis, L. R. Malabarba \& S. B. Mallmann cols. (MCP 11046); Augusto Pestana (rio Conceição, 28 $8^{\circ} 32^{\prime} \mathrm{S} 5^{\circ} 58^{\prime} \mathrm{W}$ ), 159,8mm CP, 11.IX.86, C. P. Silva \& M. F. Korndorfer cols. (MCP 10851).

Diagnose. Rineloricaria reisi se distingüe das demais espécies do gênero pelo abdome parcialmente coberto por um conjunto de séries irregulares de pequenas placas, diminuindo no sentido anterior e precedendo a placa pré-anal, não atingindo a altura da inserção das nadadeiras peitorais; pela região da cintura escapular nua e por um conjunto de pequenas placas localizado abaixo das aberturas branquiais contatando as placas abdominais laterais. Em acréscimo, a seguinte combinação ajuda a diferenciá-la das outras espécies: ponta do focinho com uma área nua ovalada não se estendendo posteriormente e nadadeiras peitorais atingindo do primeiro terço a metade das nadadeiras pélvicas. Rineloricaria reisi assemelha-se a $R$. misionera pelo abdome parcialmente coberto de placas, mas nesta última espécie as séries abdominais contatam as placas abdominais laterais (o que não ocorre em $R$. reisi); diferencia-se de $R$. maquinensis por não apresentar as placas retangulares junto à base das nadadeiras pélvicas, características daquela espécie.

Descrição. Dados morfométricos apresentados na Tabela IV. Corpo achatado, fortemente deprimido no pedúnculo caudal, afilando-se posteriormente a partir das nadadeiras peitorais. Perfil dorsal levemente convexo da ponta do focinho à inserção da nadadeira dorsal, declinando levemente até tornar-se reto no final do pedúnculo caudal. 
Perfil anterior da cabeça em vista dorsal triangular. Odontodes pequenos e conspícuos sobre o pterótico composto, crista discreta originada na ponta do focinho, desaparecendo anteriormente às órbitas. Par de cristas divergentes no parieto-supraoccipital e pré-dorsais suaves. Ponta do focinho com área nua ovalada não alcançando o poro mais anterior do canal sensorial infraorbital na margem inferior do focinho. Borda superior da órbita saliente, estendendo-se anteriormente; entalhe pós-orbital com aproximadamente a metade do olho; órbita $0,8 \mathrm{vez}$ na distância interorbital. Olho arredondado a ovalado, íris parcialmente coberta por um pequeno divertículo.

Lábio inferior bem desenvolvido, coberto com pequenas papilas e margem com franja discreta; duas fileiras de papilas bem visíveis separam o lábio inferior do superior; barbilhão maxilar presente com tamanho aproximado ao do sulco pós-orbital. Dentes afilados e bilobados com as cúspides internas mais longas; 6-10 dentes no pré-maxilar, 6-11 dentes no dentário maiores que os superiores.

Vinte e nove placas na série média (placas laterais da série pós-cleitral). Placas da série média e série médioventral com quilhas ásperas, confluentes, com odontodes conspícuos nas extremidades, coalescendo-se nas últimas 9-11 placas. Linha lateral completa, os poros abrindo-se na série média de placas, e estendendo-se até a placa central das placas supracaudais.

Oito a dez placas abdominais laterais alongadas, localizadas entre a base das nadadeiras peitorais e inserção das nadadeiras pélvicas. Abdome revestido parcialmente: há um conjunto de placas médias precedendo uma grande placa pré-anal, menores e ovaladas anteriormente. Anterior a este conjunto (e lateralmente as placas abdominais laterais) o abdome é totalmente nu. Pequenas placas formam um conjunto justamente posterior às aberturas branquiais.

Dorsal i+7; raio indiviso menor que comprimento da cabeça. Peitoral i+6; quando adpressa ao corpo, atingindo o primeiro terço a metade da nadadeira pélvica; raios cobertos por odontodes hipertrofiados de pontas curvas nos machos sexualmente maduros. Pélvica $i+5$, não atingindo a inserção da nadadeira anal e não se estendendo além da margem posterior da segunda placa após a papila anal. Anal i+5. Caudal i+10+i; raio indiviso superior da nadadeira caudal maior que o raio inferior; borda posterior da nadadeira caudal levemente côncava.

Colorido em álcool. Superfície dorsal castanha, mais escura na cabeça e numa faixa transversal difusa na região

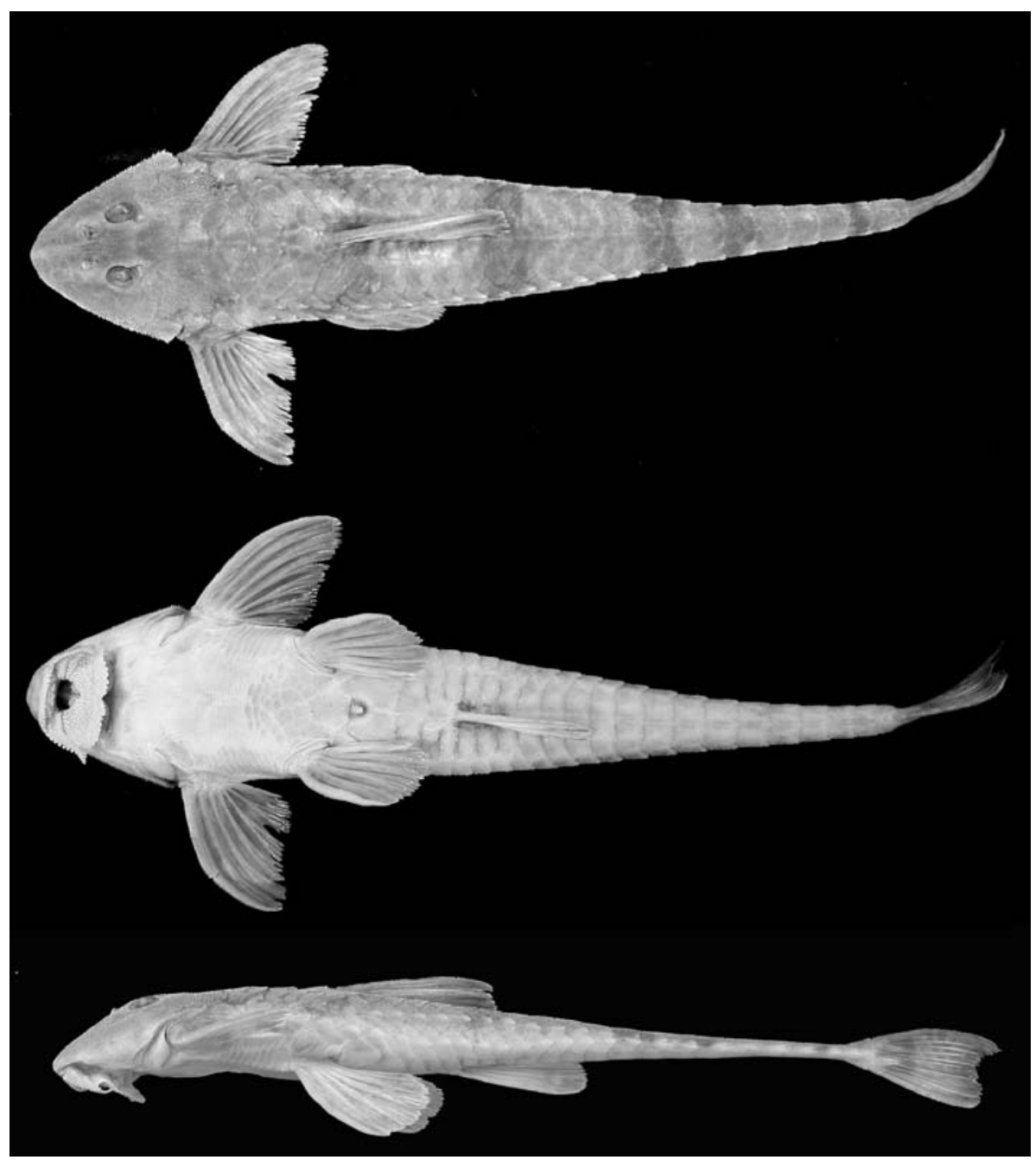

Fig. 9. Rineloricaria reisi sp. nov. holótipo MZUSP 28748, ơ, 168mm CP, rio Piratini na Fazenda Hinz, distrito de Coimbra, Santo

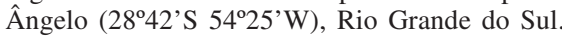


occipital. Lateral da cabeça com manchas escuras de forma e padrão irregular. Cinco faixas castanho-escuras transversais, sendo a primeira na base da nadadeira dorsal e a quinta no final do pedúnculo. Raios indivisos das nadadeiras com pontuações castanho-escuras. Nadadeiras pélvicas com pontuações conspícuas de cor castanha formando estrias. Base e extremidade da nadadeira caudal castanho-escuras, raios entre as extremidades com pontuações castanho-claras. Superfície ventral amarelada.

Distribuição. Conhecida da localidade-tipo e do rio Conceição, afluente do rio Ijuí.

Etimologia. O nome específico reisi foi dado em homenagem a Roberto E. Reis, por sua contribuição à ictiologia neotropical e principalmente pelos seus estudos de espécies da família Loricariidae. Substantivo no genitivo.

\section{Rineloricaria setepovos sp. nov. (Figs. 1, 10)}

Holótipo, Brasil, Rio Grande do Sul: Santo Ângelo (rio Piratini na Fazenda Hinz, distrito de Coimbra, $28^{\circ} 42^{\prime} \mathrm{S} 54^{\circ} 25^{\prime} \mathrm{W}$ ), o', 106mm CP, 19-20.XII.1985, R. E. Reis, L. R. Malabarba \& J. R. Stehmann cols. (MCP 19680). Parátipos, Brasil, Rio Grande do Sul: mesmos dados do holótipo, 5 ex., 57,8-92,9mm CP (MCP 19679).
Diagnose. Rineloricaria setepovos se distingüe das demais espécies do gênero pela ausência da placa pré-anal, cintura escapular e abdome sem placas, raio indiviso superior da nadadeira caudal com filamento alongado e pela presença de seis faixas transversais no dorso.

Descrição. Dados morfométricos apresentados na Tabela IV. Corpo achatado, fortemente deprimido no pedúnculo caudal, afilando-se posteriormente a partir das nadadeiras peitorais. Perfil dorsal levemente convexo da ponta do focinho à inserção da nadadeira dorsal, declinando levemente até tornar-se reto no final do pedúnculo caudal.

Perfil anterior da cabeça em vista dorsal aproximadamente triangular. Odontodes conspícuos na cabeça e região pré-dorsal, dispostos em linhas definidas no pterótico composto, bastante desenvolvidos nas laterais da cabeça dos machos sexualmente maduros. Ponta do focinho com área nua ovalada não alcançando o poro mais anterior do canal sensorial infraorbital na margem inferior do focinho. Crista originada na ponta do focinho, bifurcada entre as narinas. Par de cristas divergentes do parieto-supraoccipital e pré-dorsais conspícuas. Borda superior da órbita saliente,

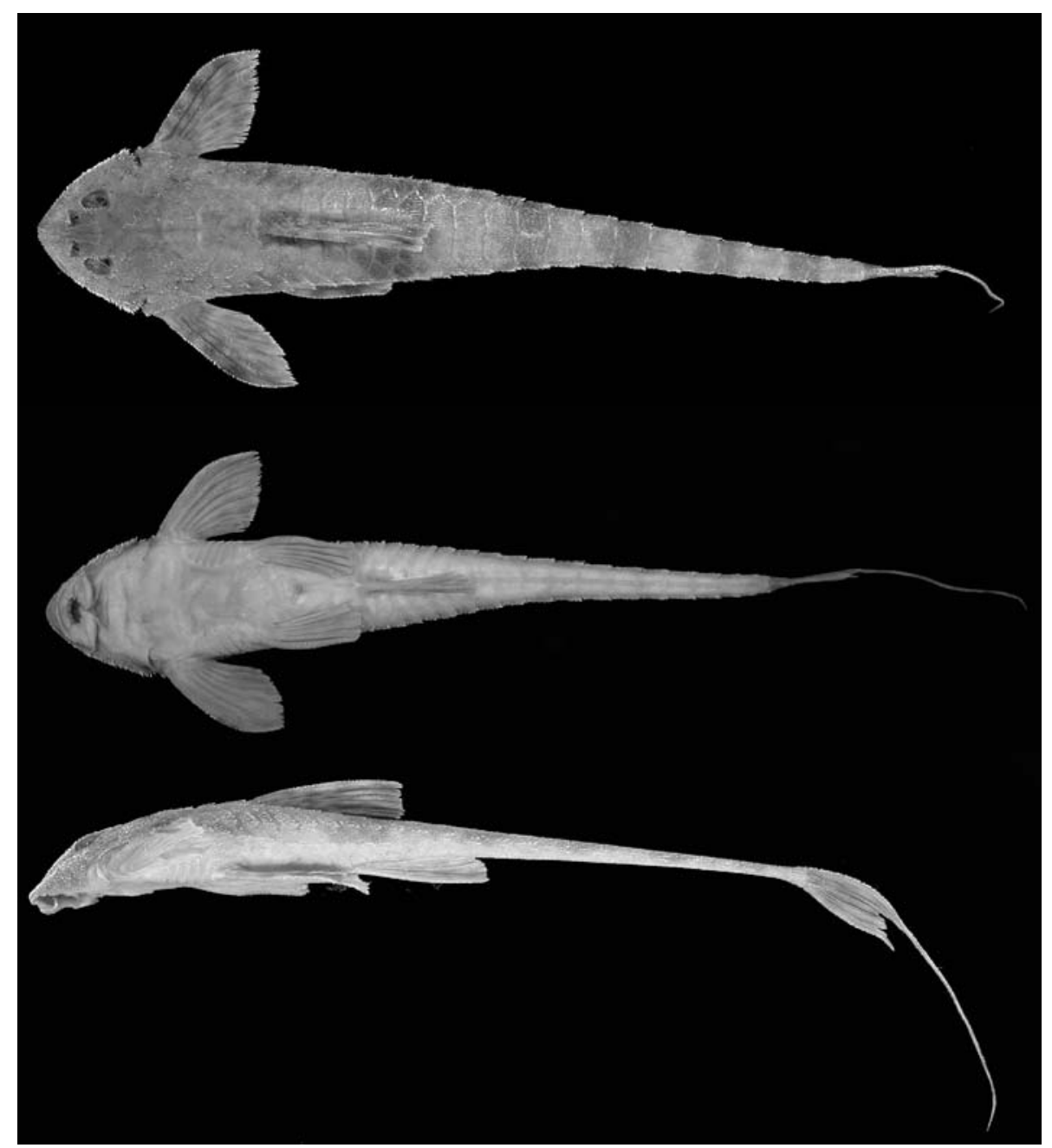

Fig. 10. Rineloricaria setepovos sp. nov. holótipo MCP 19680, ơ, 106mm CP, rio Piratini na Fazenda Hinz, distrito de Coimbra, Santo

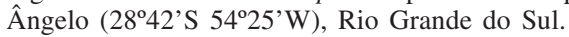


Tabela IV. Dados morfométricos do holótipo e parátipos de Rineloricaria reisi, $R$. setepovos e $R$. sanga (n, número de exemplares excluíndo holótipo).

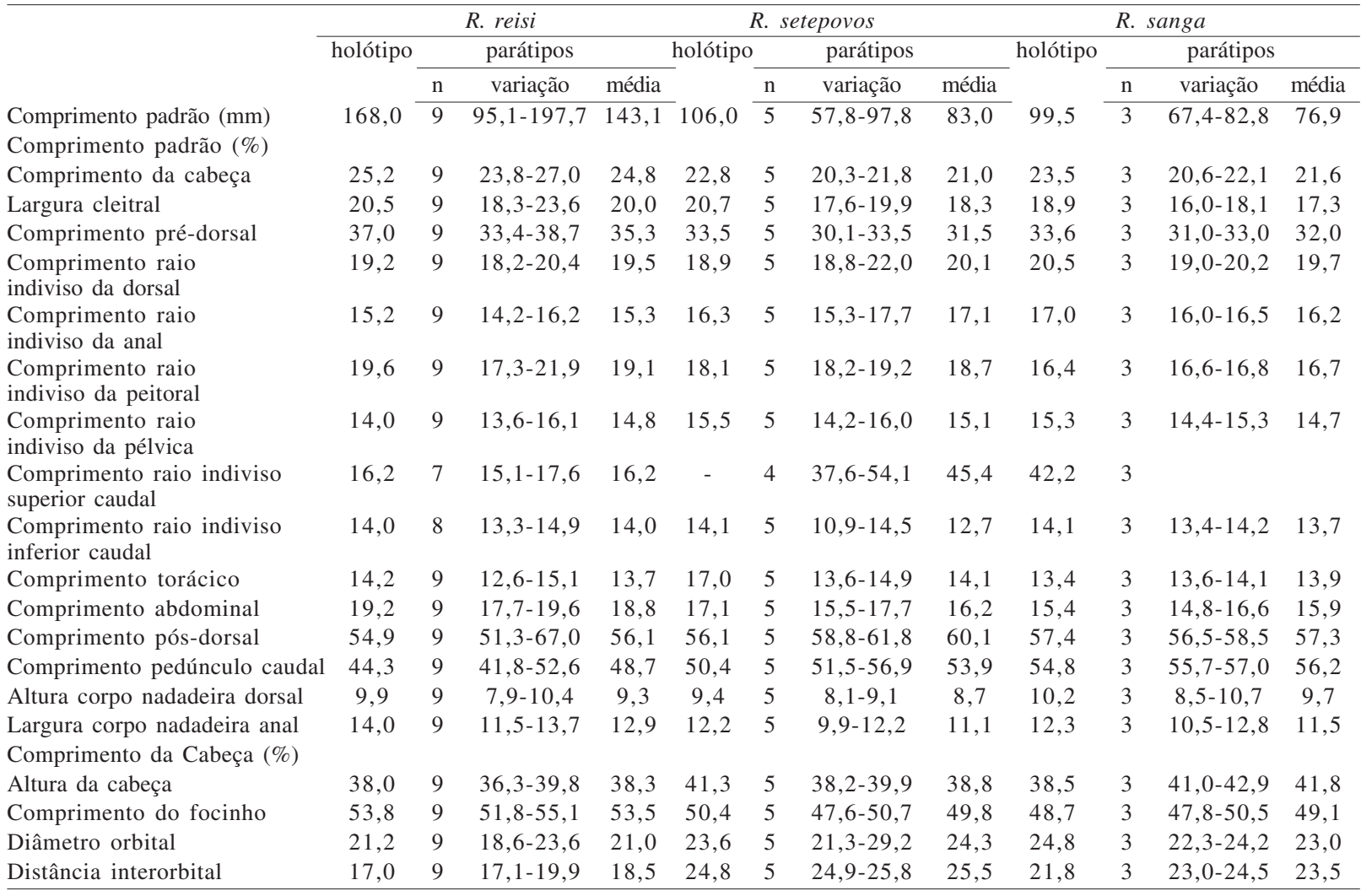

estendendo-se anteriormente; entalhe pós-orbital com aproximadamente a metade do diâmetro do olho; órbita uma vez na distância interorbital. Olho arredondado a ovalado, íris parcialmente coberta por um pequeno divertículo.

Lábio inferior bem desenvolvido, coberto com pequenas papilas e margem com franja discreta; duas fileiras de papilas bem visíveis separam o lábio inferior do superior; barbilhão maxilar presente com tamanho aproximado ao do sulco pós-orbital. Dentes afilados e bilobados com as cúspides internas mais longas; 3-4 dentes no pré-maxilar, 4-6 dentes no dentário maiores que os superiores.

Trinta placas na série média (placas laterais da série pós-cleitral). Placas da série média e série médio-ventral com quilhas ásperas, confluentes, com odontodes conspícuos nas extremidades, coalescendo-se nas últimas 13-15 placas. Linha lateral completa, os poros abrindo-se na série média de placas e estendendo-se até a placa central das placas supracaudais.

Cinco a sete placas abdominais laterais, localizadas entre a inserção do último raio ramificado das nadadeiras peitorais e inserção das nadadeiras pélvicas. Primeira placa abdominal lateral mais larga e curta que as posteriores. Região da cintura escapular e abdome totalmente desprovido de placas, inclusive placa pré-anal.

Dorsal i+7; raio indiviso menor que comprimento da cabeça. Peitoral i+6; quando adpressa ao corpo, atingindo o primeiro terço da nadadeira pélvica; raios cobertos por odontodes hipertrofiados de pontas curvas nos machos sexualmente maduros. Pélvica i +5 , por vezes tocando a inserção da nadadeira anal. Anal i+5. Caudal $\mathrm{i}+10+\mathrm{i}$; raio indiviso superior da nadadeira caudal desenvolvido em filamento alongado; borda posterior da nadadeira caudal levemente côncava.

Colorido em álcool. Superfície dorsal castanha, mais escura na cabeça e região occipital. Lateral da cabeça com manchas escuras de forma e padrão irregular. Seis faixas castanho-escuras transversais, sendo a primeira na base da nadadeira dorsal e a sexta no final do pedúnculo. Raio indiviso das nadadeiras com máculas castanhas; outros raios com pontuações formando estrias oblíquas; coloração da nadadeira dorsal acentuada em relação às outras nadadeiras. Membranas inter-radiais hialinas. Superfície ventral amarelada (a descrição detalhada do colorido desta espécie foi dificultada pois os exemplares estão escurecidos, provavelmente por algum artefato do processo de fixação).

Distribuição. Conhecida apenas da localidade-tipo.

Etimologia. O nome específico setepovos, substantivo em aposição, foi dado em alusão à região de ocorrência da nova espécie. Os "Setes Povos das Missões" no noroeste do Rio Grande do Sul originaramse das reduções jesuíticas (séc. XVII), habitadas principalmente por índios guaranis.

\section{Rineloricaria sanga sp. nov.}

(Figs. 1, 11)

Holótipo, Brasil, Rio Grande do Sul: Iraí (Sanga das Águas Frias, cerca de $100 \mathrm{~m}$ do rio Uruguai, $27^{\circ} 12^{\prime} \mathrm{S} 53^{\circ} 17^{\prime} \mathrm{W}$ ), of, 99,5mm CP, 22.XII.1985, R. E. Reis, L. R. Malabarba \& S. B. Mallmann cols. (MCP 19686). Parátipos, Brasil, Rio Grande 
do Sul: mesmos dados do holótipo, 80,6mm CP (MZUSP 41045); Palmitinho (arroio Lajeado União, Linha dos Lima, $27^{\circ} 22^{\prime} \mathrm{S}$ 533'W), 67,4mm CP, 22.XII.1985, R. E. Reis, L. R. Malabarba \& S. B. Mallmann cols. (MCP 5712). Não parátipos, Brasil, Santa Catarina: Itapiranga (arroio Santa Fé, $3 \mathrm{~km}$ a leste de Itapiranga, quase desembocadura com o rio Uruguai, $27^{\circ} 10^{\prime} \mathrm{S}$ 534ㄱ'W), 2 ex. (UFRGS 4314).

Diagnose. Rineloricaria sanga se distingüe das demais espécies do gênero pela combinação da ponta do focinho com uma pequena área nua ovalada, não se estendendo posteriormente, cristas da cabeça e dorsais conspícuas, abdome completamente coberto por três séries de placas e um filamento alongado no raio superior da nadadeira caudal. Assemelha-se a $R$. quadrensis, $R$. strigilata, $R$. felipponei, $R$. henselli, $R$. microlepidogaster e $R$. thrissoceps pela cobertura do abdome, mas diferenciase destas pelo filamento alongado da nadadeira caudal, ausente nestas espécies. Diferencia-se de $R$. microlepidogaster por apresentar menor número de séries de placas abdominais ( 3 vs. 5-6 séries), de $R$. thrissoceps pela maior distância interorbital $(21,8-24,5 \%$ vs. $19,8 \%$ no CC). Diferencia-se de R. latirostris (Boulenger, 1900) com filamento na nadadeira caudal, pelo maior comprimento do raio indiviso da nadadeira peitoral $(17,4-19,1 \%$ vs. 16,4 $16,8 \%$ no $\mathrm{CP}$ ) e ainda pelo menor comprimento do pedúnculo caudal $(51,8-53,2 \%$ vs. $54,8-57 \%$ no $\mathrm{CP})$; diferencia-se de R. kronei (Miranda-Ribeiro, 1911) e de $R$. steindachneri (ambas com filamento na nadadeira caudal) devido ao fato da primeira apresentar 4-6 séries de placas abdominais e possuir maior tamanho orbital (22,3-24,8\% vs. $18,5-21,8 \%$ no CC); e pelo fato da segunda apresentar o raio indiviso das nadadeiras peitoral e pélvica mais longo (16,4-16,8\% vs. 11,2-16\% no CP; $14,4-15,3 \%$ vs. 11,4-14,6\% no CP, respectivamente), bem como pela maior distância interorbital (21,8-24,5\% vs. 19,4-21,5\% no CC).

Descrição. Dados morfométricos apresentados na Tabela IV. Corpo achatado, fortemente deprimido no pedúnculo caudal, afilando-se posteriormente a partir das nadadeiras peitorais. Perfil dorsal levemente convexo da ponta do focinho à inserção da nadadeira dorsal, declinando levemente até tornar-se reto no final do pedúnculo caudal.

Perfil anterior da cabeça em vista dorsal triangular. Odontodes conspícuos na cabeça e região pré-dorsal, dispostos em linhas definidas sobre o pterótico composto; desenvolvidos nas laterais da cabeça dos machos sexualmente maduros. Ponta do focinho com pequena área nua ovalada não alcançando o poro mais anterior do canal sensorial infraorbital na margem inferior do focinho. Crista originada na ponta do focinho, bifurcada na região interorbital. Par de cristas divergentes do parieto-supraoccipital e pré-dorsais conspícuas; crista conspícua nas três placas situadas lateralmente de cada lado das placas pré-dorsais. Borda superior da órbita saliente, estendendo-se anteriormente; entalhe pósorbital com aproximadamente a metade do olho ou pouco maior; órbita 1,1 vezes na distância interorbital. Olho arredondado a ovalado, íris parcialmente coberta por um pequeno divertículo.

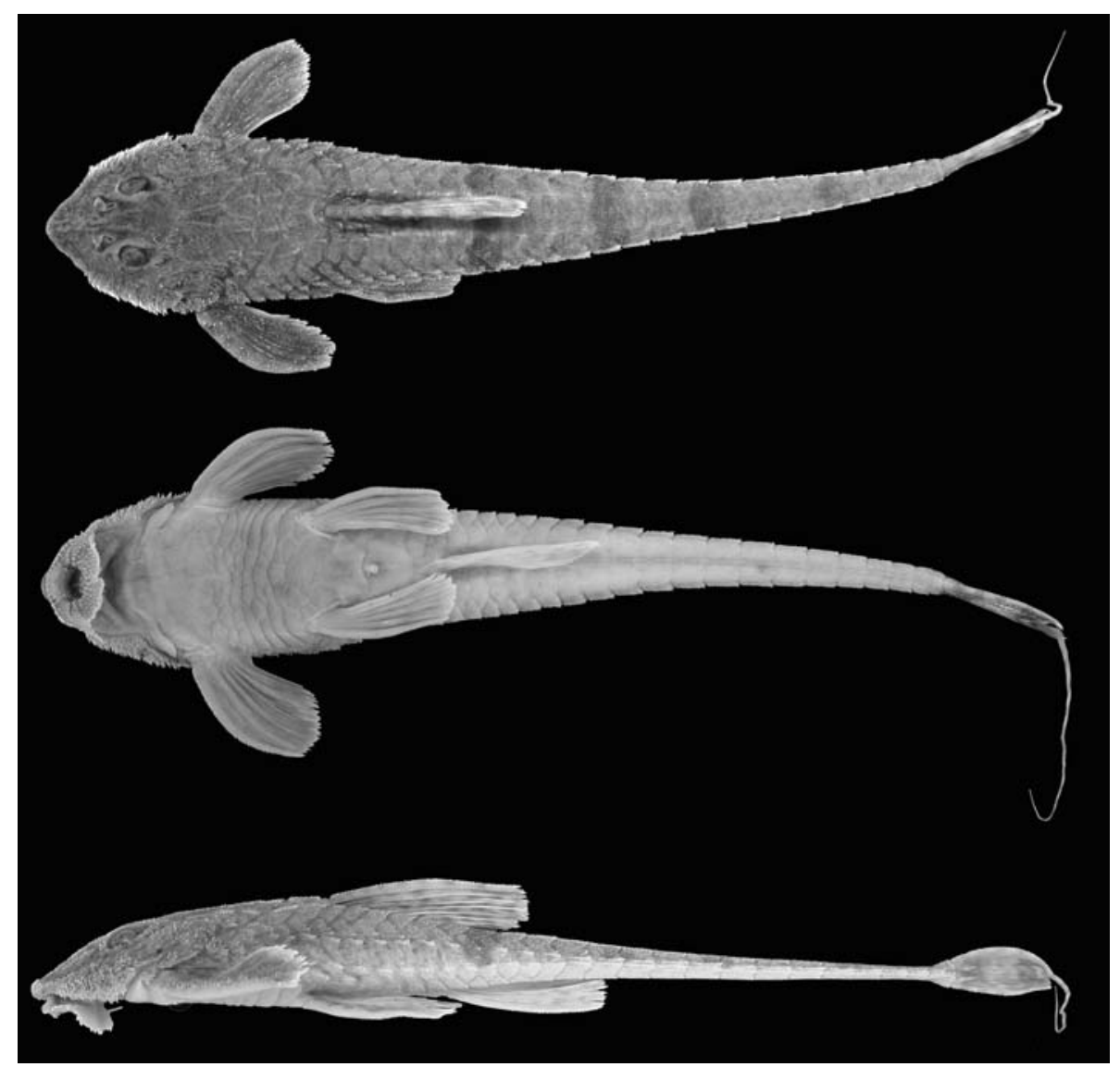

Fig. 11. Rineloricaria sanga sp. nov. holótipo MCP 19686, ơ, 99,5mm CP, Sanga das Águas Frias, cerca de 100 m do rio Uruguai, Iraí $\left(27^{\circ} 12^{\prime} \mathrm{S} 53^{\circ} 17^{\prime} \mathrm{W}\right)$, Rio Grande do Sul. 
Lábio inferior bem desenvolvido, coberto com pequenas papilas e margem com franja discreta; duas fileiras de papilas bem visíveis separam o lábio inferior do superior; barbilhão maxilar presente com tamanho aproximado ao do sulco pós-orbital. Dentes afilados e bilobados com as cúspides internas mais longas; 6-8 dentes no pré-maxilar, 6-8 dentes no dentário maiores que os superiores.

Trinta placas na série média (placas laterais da série pós-cleitral). Placas da série média e série médio-ventral com quilhas ásperas, confluentes, com odontodes conspícuos nas extremidades, coalescendo-se nas últimas 13-14 placas. Linha lateral completa, os poros abrindo-se na série média de placas e estendendo-se até a placa central das placas supracaudais.

Seis a sete placas abdominais laterais, localizadas entre a base das nadadeiras peitorais e inserção das nadadeiras pélvicas. Abdome totalmente revestido de placas. Pré-anal margeada por três placas, precedidas por outras cinco comparativamente menores. Anterior a este complexo três séries de placas pequenas. Um conjunto de placas ainda menores dispostas desordenadamente reveste a região da cintura escapular.

Dorsal i+7; raio indiviso menor que o comprimento da cabeça. Peitoral i+6; quando adpressa ao corpo, atingindo o primeiro terço da nadadeira pélvica; raios cobertos por odontodes hipertrofiados de pontas curvas nos machos sexualmente maduros. Pélvica i+5, tocando a inserção da nadadeira anal. Anal i+5. Caudal i+10+i; raio indiviso superior da nadadeira caudal com filamento; borda posterior da nadadeira caudal levemente côncava.

Colorido em álcool. Superfície dorsal castanha, mais escura na cabeça e numa faixa transversal difusa na região occipital. Lateral da cabeça com pigmentação escura formando padrão marmoreado. Cinco faixas castanho-escuras transversais, sendo a primeira na base da nadadeira dorsal e a quinta no final do pedúnculo. Raios da nadadeira dorsal com pontuações marrons; nadadeiras pares com pontuações pouco conspícuas. Membranas inter-radiais hialinas. Nadadeira caudal com pigmentação castanha concentrada na base e extremidade distal; restante da nadadeira com pontuações discretas. Superfície ventral amarelada.

Distribuição. Conhecida apenas dos arredores do município de Iraí, em riachos afluentes do rio Uruguai.

Etimologia. O nome específico sanga, substantivo em aposição, originado da palavra castelhana "zanja", foi dado em alusão à localidade de coleta da nova espécie. Sanga é uma expressão utilizada correntemente no Rio Grande do Sul e Santa Catarina para designar córrego ou pequeno riacho.

\section{DISCUSSÃO}

Das 58 espécies de Rineloricaria ocorrentes na América do Sul, dez ocorrem no alto e médio rio Uruguai, que apresenta uma riqueza de espécies deste gênero muito mais alta que outras bacias do escudo brasileiro. $\mathrm{O}$ alto rio Paraná, por exemplo, com uma área de drenagem muito maior, possui apenas duas espécies, $R$. latirostris e $R$. pentamaculata (GHAZZI \& OYAKAMA, 2007). O rio Iguaçu, com aproximadamente a mesma extensão do alto e médio rio Uruguai, apresenta duas espécies de Rineloricaria, ainda não descritas (INGENITO et al., 2004; obs. pess.). Da vasta área de abrangência do rio Paraíba do Sul apenas três espécies são conhecidas, $R$. steindachneri, $R$. nigricauda (GHAZZI \& OYAKAMA, 2007) e uma espécie não descrita (obs. pess.). Igualmente, o rio Ribeira de Iguape abriga apenas quatro espécies: $R$. kronei (GHAZZI \& OYAKAMA, 2007) e três não descritas (OYAKAMA et al., 2006; obs. pess.). Toda a bacia do rio Paraguai abriga apenas três espécies nominais (GHAZZI \& OYAKAMA, 2007) $R$. hoehnei (Miranda-Ribeiro, 1912), R. cacerensis (Miranda-Ribeiro, 1912) e R. parva (Boulenger, 1895) e o rios São Francisco e Doce, apresentam cada um, uma única espécie ainda não descrita (ReIs \& CARDoso, 2001; obs. pess.).

Este fenômeno de riqueza de espécies no rio Uruguai não ocorre somente com Rineloricaria. Das 74 espécies nominais assinaladas por KULLANDER (2003) para o gênero Crenicichla Heckel, 1840, 11 ocorrem na bacia do rio Uruguai. ReIs et al. (1990) registraram oito espécies das 116 do gênero Hypostomus Lacepède, 1803, no rio Uruguai. O pseudopimelodídeo Microglanis Eigenmann, 1912 contém 13 espécies distribuídas na América do Sul de ambos os lados dos Andes, sendo três delas do rio Uruguai (Bertaco \& CARdoso, 2005). Hemiancistrus Bleeker, 1862 com 19 espécies ocorrendo do Panamá ao sul do Brasil, tem quatro espécies restritas ao rio Uruguai (CArdoso \& Silva, 2004). Finalmente, o gênero Gymnogeophagus Miranda-Ribeiro, 1918 possui nove espécies descritas (Kullander, 2003), além de sete espécies ainda não descritas, sendo que quatro ocorrem no alto Uruguai (Roberto E. Reis com. pess.).

A hipótese de que a riqueza de espécies de Rineloricaria no rio Uruguai se deve à intensidade das coletas nesta bacia nos últimos anos parece insuficiente, visto que também as bacias dos rios Paraná, Iguaçu, Paraguai, São Francisco, Ribeira de Iguape e Paraíba do Sul (razoavelmente bem amostradas) apresentam poucas espécies de Rineloricaria. A complexa origem do rio Uruguai no Plioceno e no Pleistoceno inferior (LATRUBESSE et al., 2005) pode ter colaborado de alguma forma com a diversidade de peixes desta bacia.Todavia não é possível afirmar com certeza o que gerou a riqueza de espécies encontrada hoje no rio Uruguai. Talvez, eventos naturais (geológicos e evolutivos), somados à enorme diversidade de habitats existentes na região, expliquem a grande diversidade de espécies lá encontrada.

Todas as espécies aqui descritas diferenciam-se de $R$. aequalicuspis pelo tamanho das cúspides dentárias. Nas espécies conhecidas do gênero, as cúspides internas são mais longas que as externas. Entretanto, Rineloricaria aequalicuspis apresenta um padrão exclusivo: cúspides de tamanho aproximadamente igual em ambas as maxilas (Reis \& CARdoso, 2001). Rineloricaria cacerensis, $R$. hoehnei, $R$. parva diferenciam-se de todas as espécies aqui descritas por apresentarem duas faixas escuras na cabeça, da ponta do focinho até os olhos, ou além destes. Além disso, $R$. cacerensis apresenta pontuações dorsais conspícuas. Rineloricaria strigilata também é facilmente diferenciada das espécies do rio Uruguai pelo padrão de colorido conspícuo com pequenas manchas distribuídas por toda a face dorsal, ausente nas mesmas. 
Rineloricaria cubataonis (Steindachner, 1907) apresenta a cintura peitoral coberta de pequenas placas, as quais podem ser muito pequenas (como pontos) e uma faixa longitudinal sem placas entre as placas abdominais laterais e as séries abdominais. Esta espécie ainda pouco conhecida parece apresentar variação intra-específica da cobertura do abdome (obs. pess.) mas, apesar de apresentar áreas nuas na cobertura abdominal, é facilmente diferenciada das espécies do rio Uruguai por possuir quatro faixas dorsais (vs. 5-6 nestas espécies).

Além da comparação com as espécies de Rineloricaria que ocorrem na República do Uruguai, do sul ao sudeste do Brasil e no sistema do rio ParanáParaguai, também a revisão bibliográfica de 14 espécies que ocorrem na bacia Amazônica (incluindo comparações com suas respectivas descrições) provou que as mesmas são distintas das espécies descritas do rio Uruguai. As espécies $R$. tropeira, $R$. anhanguapitan, R. capitonia, $R$. setepovos e $R$. reisi (cuja região abdominal é parcialmente nua) são facilmente diferenciadas das amazônicas (que apresentam a região ventral revestida de placas). Desta forma, a análise das descrições enfatizou a diferenciação das espécies amazônicas de suas congêneres do rio Uruguai com placas no abdome e região escapular.

Rineloricaria heteroptera Isbrücker \& Nijssen, 1976, R. lanceolata (Günther, 1868), R. formosa Isbrücker \& Nijssen, 1979 e R. castroi Isbrücker \& Nijssen, 1984 apresentam padrão de colorido distintivo na superfície dorsal e nas nadadeiras (ver ISBRÜCKER \& NIJSSEN, 1976: fig. 2, 3; ISBRÜCKER, 1973: fig. 2; ISBRÜCKER \& NIJSSEN, 1979: fig. 2; ISBRÜCKER \& NIJSSEN, 1984: fig. 1) que as diagnosticam de todas suas congêneres.

As espécies $R$. phoxocephala (Eigenmann \& Eigenmann, 1889), R. fallax (Steindachner, 1915), $R$. morrowi Fowler, 1940, R. melini (Schindler, 1959), $R$. hasemani Isbrücker \& Nijssen, 1979 e R. platyura (Müller $\&$ Troschel, 1848) apresentam a cabeça longa medindo no comprimento padrão respectivamente $4,8-5,1$ vezes; 5,5 vezes; 5,4 vezes; 5,7 vezes; 5,2 e 5-5,4 vezes. Em $R$. zaina (4-4,5 vezes), $R$. anitae (4,2-4,6 vezes), $R$. sanga (4,3-4,8 vezes) e $R$. stellata (4,1-4,7 vezes) o comprimento da cabeça é um pouco menor que nestas espécies.

Rineloricaria teffeana (Steindachner, 1879) e $R$. konopickyi (Steindachner, 1879) apresentam seis listras transversais no dorso. Dentre as espécies do rio Uruguai, apenas $R$. setepovos tem este padrão de colorido (todavia, esta espécie tem o abdome totalmente nu, o que não ocorre nestas espécies).

Um filamento alongado no raio superior da nadadeira caudal é diagnóstico para $R$. wolfei Fowler, 1940 , o que a diferencia de $R$. anitae, $R$. zaina e $R$. stellata. Rineloricaria sanga pode ser diferenciada de $R$. wolfei por apresentar três séries de placas abdominais ( $v s$. quatro séries na espécie amazônica).

As espécies $R$. anitae e $R$. zaina diferenciam-se de $R$. beni (Pearson, 1924) pelas 5-6 séries de placas abdominais $v s$. três séries nesta espécie; $R$. beni também é distinta por ter distância interorbital (3,3-3,5 vezes no CC) menor que nas espécies $R$. anitae (4,3-4,6 vezes), $R$. zaina (3,8-4,5 vezes), $R$. sanga (4,1-4,6 vezes) e $R$. stellata (3,8-4,4 vezes).
Entre todas as espécies de Rineloricaria examinadas ao longo deste trabalho, apenas $R$. setepovos apresenta o abdome totalmente nu. $\mathrm{O}$ gênero Ixinandria é o único outro integrante da subtribo Rineloricariina com esta característica. ISBRÜCKER (1979) afirma que Ixinandria distingue-se do gênero Rineloricaria pelo abdome nu e que algumas espécies de Rineloricaria podem ter o abdome incompletamente coberto de placas dérmicas. A afirmação daquele autor pode ser facilmente confirmada na variação encontrada em várias espécies de Rineloricaria: cintura escapular com pequenas placas ou placas ausentes (e.g. R. misionera), ausência de placas apenas na cintura escapular (e. g. R. anhaguapitan, Rineloricaria sp. dos sistemas costeiros do Rio de Janeiro), placas recobrindo apenas metade do abdome (e. g. R. tropeira), placas em uma área mediana do abdome mas sem contato com as placas abdominais laterais (e. $g$. $R$. reisi, $R$. aequalicuspis), abdome nu, mas com um conjunto de placas adjacentes a pré-anal (e. $g . R$. maquinensis) e por fim o padrão encontrado em $R$. setepovos, abdome e cintura escapular totalmente descobertos. É interessante ressaltar que nos sistemas hidrográficos dos rios Amazonas, Paraguai e rios transandinos da América do Sul, as espécies de Rineloricaria apresentam o abdome e região escapular revestidos por placas. Embora Rineloricaria não seja um grupo com monofiletismo demonstrado, seria interessante verificar o nível de informação presente neste caráter (ausência/presença de placas abdominais), pois a ausência de placas abdominais compartilhada apenas por espécies ocorrentes nas bacias do leste do Brasil, rios Paraná e Uruguai poderia sugerir uma ancestralidade comum ao grupo de espécies nesta região.

Considerando a variação interespecífica de Rineloricaria e a hipótese de seu parafiletismo (RAPP Py-Daniel \& Cox Fernandes, 2005), Ixinandria que também não tem seu monofiletismo investigado poderia constituir um grupo com Rineloricaria, possibilidade já considerada por REIS \& CARDOSO (2001). Alternativamente, poderia tratar-se de um grupo distal à este (à semelhança da relação entre os gêneros Brochis e Corydoras; REIs, 1998; BRITTO, 2003). Entretanto, Ixinandria steinbachi (Regan, 1906), a espécie tipo do gênero, apresenta os dentes distintos das espécies de Rineloricaria. Esta característica a qual poderá ser futuramente tratada apenas como uma diferença interespecífica foi relevante para distinguir $R$. setepovos do gênero Ixinandria. A espécie I. steinbachi apresenta dentes numerosos (6-15 em cada série), com lóbulos largos, pouco distintos em comprimento e com cúspides de margens retas (fêmeas) a arredondadas (machos). Ixinandria steinbachi também pode ser diferenciada de $R$. setepovos por não apresentar filamento no raio superior da nadadeira caudal.

Material comparativo examinado. Rineloricaria aequalicuspis: Brasil, Rio Grande do Sul: rio Três Forquilhas, parátipos, 24 ex. (MCP 10795); Santa Catarina: rio Araranguá, 25 ex. (MCP 10618); idem, 4 ex. (MZUSP 37707). Rineloricaria cadeae: Brasil, Rio Grande do Sul: lagoa dos Patos, 15 ex. (MCP 11108); idem, 6 ex. (MCP 9727); rio Jacuí, 6 ex. (MCP 17499); idem, 12 ex. (MCP 19431). Rineloricaria catamarcensis: ARGENTINA, Tucumán: río Salí, 1 ex. (FML 069). Rineloricaria cacerensis: Brasil, Mato Grosso: rio Paraguai, 3 ex., cotótipos, (MNRJ 645). Rineloricaria cf. cubataonis: Brasil, Santa 
Catarina: rio Itajaí-Açu, 22 ex. (MCP 16266); rio Cubatão, 4 ex. (MCP 17478). Rineloricaria felipponei: URUGUAI, holótipo (ANSP 70324). Rineloricaria hoehnei: Brasil, Mato Grosso: rio Paraguai, holótipo (MNRJ 650). Rineloricaria jaraguensis: Brasil, Santa Catarina: Jaraguá (= rio Itapocu), lectótipo (NMW 44886); idem, paralectótipo (NMW 44883); rio Piraí, 10 ex. (MZUSP 24579). Rineloricaria kronei: Brasil, São Paulo: rio Ribeira de Iguape, 4 ex. (MZUSP 58889); idem, 8 ex. (MZUSP 60228). Rineloricaria lanceolata: Brasil, Rondônia: rio Madeira, 35 ex. (MNRJ 14972). Rineloricaria latirostris: Brasil, Mato Grosso do Sul: rio Paraná, 15 ex. (MZUSP 24447); São Paulo: rio Paraná, 10 de 20 ex. (MZUSP 3107); idem, 3 ex. (MZUSP 22742); idem, 6 ex. (MZUSP 83672); idem, 1 ex. (MZUSP 22471); idem, 4 ex. (MZUSP 24979); idem, 4 ex. (MZUSP 24979); idem, 3 ex. (MZUSP 22641). Rineloricaria longicauda: BRASIL, Rio Grande do Sul: banhado do Taim, holótipo (MZUSP 16078); idem, 1 ex., parátipo (MAPA 1337); idem, 1 ex., parátipo (MAPA 1338); idem, 1 ex., parátipo (MAPA 1339); idem, 1 ex., parátipo (MAPA 1333); idem, 1 ex., parátipo (UFRGS 574). Rineloricaria maquinensis: BRASIL, Rio Grande do Sul: rio Maquiné, 1 ex., parátipo (MZUSP 27347); idem, 2 ex., parátipos (MAPA 1258); idem, 14 ex., parátipos (MCP 10769); Santa Catarina: rio Araranguá, 6 ex. (MCP 10622). Rineloricaria microlepidogaster: BRASIL, Rio Grande do Sul: lagoa dos Patos, 1 ex. (MCP 17234); idem, 1 ex. (MNRJ 22232); rio Jacuí, 2 ex. (MCP 17251); rio Jaguarão, 1 ex. (MCP 11266). Rineloricaria misionera: ARGENTINA, Misiones: 3 ex., parátipos (MCP 35793). Rineloricaria nigricauda: BRASIL, Rio de Janeiro: rio Paraíba do Sul, lectótipo (BMNH 1891.6.16.32); idem, 20 ex. (MNRJ 14017); idem, 29 ex. (MNRJ 13955). Rineloricaria pareiacantha: URUGUAI: rio Santa Lucia, holótipo (ANSP 67815). Rineloricaria parva: BRASIL, Mato Grosso: rio Paraguai, 5 ex. (MCP 15703). PARAGUAI, Central: rio Paraguai, 2 ex. (MNRJ 23315); idem, 6 ex. (MNRJ 23316). Rineloricaria pentamaculata: BRASIL, São Paulo: rio Paraná, holótipo (MZUSP 43501); parátipo (MZUSP 43502); idem, 2 ex., parátipos (MZUSP 43503); Minas Gerais: rio Paraná, 2 ex., parátipos (MZUSP 38892); Goiás: rio Paraná, 1 ex. (MNRJ 26390); idem, 1 ex. (MNRJ 26391). Rineloricaria quadrensis: BRASIL, Rio Grande do Sul: lagoa dos Quadros, 4 ex. (MCP 15268); idem, 4 ex. (MCP 9548); idem, 3 ex. (MCP 13598). Rineloricaria steindachneri: BRASIL, Rio de Janeiro: rio Paraíba do Sul, lectótipo (NMW 45016:1); idem, paralectótipo (NMW 45013:2); idem, 4 ex. (MNRJ 13375); idem, 10 ex. (MNRJ 14007). Rineloricaria strigilata: BRASIL, Rio Grande do Sul: rio Jacuí, 16 ex. (MCP 9787); idem, 12 ex. (MCP 14176); idem, 2 ex. (MCP 19433). Rineloricaria thrissoceps: URUGUAI: rio Santa Lucia, holótipo (ANSP 67796). Rineloricaria sp. "b": BRASIL, Rio Grande do Sul: rio Jacuí, 7 ex. (MAPA 1329); idem, 3 ex. (MAPA 1270). Rineloricaria sp. "fl” BRASIL, São Paulo: rio Ribeira de Iguape, 19 ex. (MZUSP 51943). Rineloricaria sp. "g": BRASIL, Rio de Janeiro: rio Macacu, 5 ex. (MNRJ 17797). Rineloricaria sp."h": BRASIL, Rio Grande do Sul: rio Jacuí, 12 ex. (MCP 11478). Rineloricaria sp. "i" : BRASIL, Rio Grande do Sul: rio Taquari, 1 ex. (MZUSP 27658); idem, 1 ex. (MAPA 1492). Rineloricaria sp. "lr": BRASIL, São Paulo: rio Ribeira de Iguape, 17 ex. (MZUSP 40022). Rineloricaria sp. "lp": BRASIL, Rio de Janeiro: rio Paraíba do Sul, 34 ex. (MNRJ 13961). Rineloricaria sp. "m": BRASIL, Rio Grande do Sul: rio dos Sinos, 3 ex. (MAPA 1261). Rineloricaria sp. "p": BRASIL, Rio de Janeiro: rio Guandu, 7 ex. (MNRJ 17484). Rineloricaria sp. "t": BRASIL, Rio de Janeiro: baía de Guanabara, 42 ex. (MNRJ 15126). Rineloricaria spp.: BRASIL, Paraná: rio Nhundiaquara, 11 ex. (MHNCI 6576); rio Serra Negra, 9 ex. (MHNCI 6368); rio Iguaçu, 10 ex. (MHNCI 4969); Minas Gerais: rio São Francisco, 6 ex. (MNRJ 14162); Bahia: rio São Francisco, 4 ex. (MNRJ 22855); Mato Grosso: rio Arinos, 18 ex. (MNRJ 23278). Ixinandria steinbachi: ARGENTINA, La Caldera: rio Pilcomayo, 1ex. (MCNI 186); idem, 2 ex. (MCNI 331); Capital: rio Pilcomayo, 4 ex. (MCNI 419).

Agradecimentos. Aos colegas do Laboratório de Ictiologia (MCP) durante o período do mestrado: R. E. dos Reis, L. R Malabarba, C. A. S. de Lucena, Z. M. Lucena, G. M. Guazzelli, W. R. Koch, L. Hahn, E. H. Pereira, E. S. Vidal, J. F. P. da Silva, V. Bertaco e A. R. Cardoso. Pelo empréstimo de material e recepção nas respectivas instituições: L. R. Malabarba (UFRGS), F. Meyer (MAPA), K. Grosser (MCN), J. L. de Figueiredo e O. T. Oyakawa (MZUSP), Z. M. Lucena (MCP), P. A. Buckup (MNRJ), I. J. H. Isbrücker (ZMA), V. Abilhoa (MHNCI) e H. Wellendorf (NMW). M. R. de Britto (MNRJ), A. L. Netto-Ferreira e L. F. da S. Ingenito deram valiosas sugestões ao manuscrito. A M. Rodriguez pelo acesso aos exemplares de Ixinandria steinbachi do MCNI. A R. E. dos Reis (MCP) pelas fotos da Figura 7. Ao CNPq pelas bolsas de Mestrado e Pós-Doutorado.

\section{REFERÊNCIAS BIBLIOGRÁFICAS}

Aquino, A. E. \& Schaefer, S. A. 2002. The temporal region of the cranium of loricarioid catfishes (Teleostei: Siluriformes): morphological diversity and phylogenetic significance. Zoologischer Anzeiger 241:223-224.

Arratia, G. \& Gayet, M. 1995. Sensory canals and related bones of Tertiary siluriform crania from Bolivia and North America and comparison with recent forms. Journal of Vertebrate Paleontology 15:482-505.

Bertaco V. A. \& Cardoso, A. R. 2005. A new species of Microglanis (Siluriformes: Pseudopimelodidae) from the rio Uruguay drainage, Brazil. Neotropical Ichthyology 3(1):61-67.

Bertoletti, J. J.; Lucena, C. A. S. de; Lucena, Z. M. S. de; Malabarba, L. R. \& ReIs, R. E. Dos. 1989a. Ictiofauna do rio Uruguai superior entre os municípios de Aratiba e Esmeralda, Rio Grande do Sul, Brasil. Comunicações do Museu de Ciências e Tecnologia da PUCRS, Série Zoologia, 48:3-42.

1989b. Ictiofauna do rio Canoas, Sistema do rio Uruguai superior, Campos Novos, Santa Catarina, Brasil. Comunicações do Museu de Ciências e Tecnologia da PUCRS, Série Zoologia, 49:43-75.

BRITTO, M. R. de. 2003. Phylogeny of the subfamily Corydoradinae Hoedeman, 1952 (Siluriformes: Callichthyidae), with a definition of its genera. Proceedings of the Academy of Natural Science of Philadelphia 153:119-154.

Burgess, W. E. 1989. An atlas of freshwater and marine catfishes: a preliminary survey of the Siluriformes. Neptune, T. F. H. 784p.

Cardoso, A. R. \& Silva, J. F. P. DA. 2004. Two new species of the genus Hemiancistrus Bleeker (Teleostei: Siluriformes: Loricariidae) from the upper rio Uruguai basin. Neotropical Ichthyology 2(1):1-8.

Eschmeyer, W. N. 1998. Catalog of fishes. 3v. San Francisco, California Academy of Sciences. 2905p.

Evers, H-G. \& Seidel, I. 2002. Wels Atlas Bd.1: Südamerikanische Welse der Familien Loricariidae, Cetopsidae, Nematogenyidae und Trichomycteridae. Melle, Mergus Verlag. 860p.

Ferraris, C. J., JR. 2003. Subfamily Loricariinae (Armored catfishes). In: Reis, R. E.; Kullander, S. O. \& Ferraris, C. J., JR. eds. Check list of the freshwater fishes of South and Central America. Porto Alegre, EDIPUCRS. p.330-350.

Fowler, H. W. 1954. Os peixes de água doce do Brasil (4 ${ }^{\mathrm{a}}$ entrega). Arquivos de Zoologia do Estado de São Paulo 9:1-400

Ghazzi, M. S. 2005. Sturisoma kneri, new species, a name for an old yet poorly-known catfish (Siluriformes: Loricariidae). Copeia 3:559-565.

Ghazzi, M. S. \& Oyakawa, O. T. 2007. Família Loricariidae: Loricariinae. In: Buckup, P. A.; Menezes, N. A. Ghazzi, M. S. eds. Catálogo das espécies de peixes de água doce do Brasil. Rio de Janeiro, Museu Nacional. p.87-91.

GosLine, W. A. 1945. Catálogo dos nematognatos de água doce da América do Sul e Central. Boletim do Museu Nacional, nova série, Zoologia 33:1-138.

Ingenito, L. F. S.; Duboc, L. F. \& AbilhoA, V. 2004. Contribuição ao conhecimento da ictiofauna da bacia do alto rio Iguaçu, Paraná, Brasil. Arquivos de Ciências Veterinárias e Zoologia da UNIPAR 7(1):23-36.

ISBRÜCKER, I. J. H. 1973. Redescription and figures of the South American catfish Rineloricaria lanceolata (Günther, 1868) (Pisces, Siluriformes, Loricariidae). Beaufortia 21(278):75-89.

1979. Descriptions préliminaires de noveaux taxa de la familie des loricariidae. Revue Française d'Aquariologie, Herpetologie 5(4):86-116. 
1980. Classification and catalogue of the mailed Loricariidae (Pisces, Siluriformes). Verslagen en Technische Gegevens 22:1-181.

2001. Nomenklator der Gattungen und Arten der Harnischwelse, Familie Loricariidae Rafinesque, 1815 (Teleostei, Ostariophysi). Datz - Sonderheft Harnischwelse 2:25-32.

ISBRÜCKER, I. J. H. \& NIJSSEN, H. 1976. Rineloricaria heteroptera, a new species of mailed catfish from rio Amazonas near Manaus, Brazil (Pisces, Siluriformes, Loricariidae). Zoologischer Anzeiger 196(1/2):109-124.

1978. Two new species and a new genus of Neotropica mailed catfishes of the subfamily Loricariinae Swainson, 1838 (Pisces, Siluriformes, Loricariidae). Beaufortia 27(339):177-206. 1979. Three new South American mailed catfishes of the genera Rineloricaria and Loricariichthys (Pisces, Siluriformes, Loricariidae). Bijdragen Tot de Dierkunde 48(2):191-211. 1984. Rineloricaria castroi, a new species of mailed catfishes from rio Trombetas, Brazil (Pisces, Siluriformes, Loricariidae). Beaufortia 34(3):93-99.

KnAack, J. 2003. Ein neuer Prachthexenwels aus Paraguay: Hemiloricaria aurata n. sp. (Pisces, Siluriformes, Loricariidae). Aquaristik aktuell 1:56-61.

Kullander, S. O. 2003. Family Cichlidae (Cichlids). In: ReIs, R. E.; Kullander, S. O. \& Ferraris, C. J., Jr. eds. Check list of the freshwater fishes of South and Central America. Porto Alegre, EDIPUCRS. p.605-654.

Langeani, F. \& Araujo, R. B. DE. 1994. O gênero Rineloricaria Bleeker, 1862 (Ostariophysi, Siluriformes) na bacia do rio Paraná superior: Rineloricaria pentamaculata sp. n. Rineloricaria latirostris (Boulenger, 1900). Comunicações do Museu de Ciências e Tecnologia da PUCRS, Série Zoologia. 7:151-166.

Latrubesse, E. M.; Stevaux, J. C.; Santos, M. L. dos \& Assine, M. L. 2005. Grandes sistemas fluviais: geologia, geomorfologia paleoidrologia. In: Souza, C. R. de G.; Suguio, K.; Oliveira, A. M. dos S. \& Oliveira, P. E. De. eds. Quaternário no Brasil Ribeirão Preto, Holos. p.276-297.

Lucena, C. A. S. \& Kullander S. O. 1992. The Crenicichla (Teleostei: Cichlidae) species of the Uruguai River drainage in Brazil. Ichthyological Exploration of Freshwaters 3(2):97-160
Malabarba, L. R. 1989. Histórico sistemático e lista comentada das espécies de peixes de água doce do sistema da laguna dos Patos, Rio Grande do Sul, Brasil. Comunicações do Museu de Ciências e Tecnologia da PUCRS, Série Zoologia, 2(8):107-179.

Oyakawa, O. T.; Akama, A.; Mautari, K. C. \& Nolasco, J. C. 2006. Peixes de riachos da Mata Atlântica nas Unidades de Conservação do Vale do rio Ribeira de Iguape no Estado de São Paulo. São Paulo, Editora Neotrópica. 201p.

Pereira, E. H. L. \& Reis, R. E. Dos. 1992. Hemipsilichthys vestigipinnis sp. n. (Teleostei, Siluriformes) a new loricariid catfish from the rio Uruguay basin, southern Brazil. Revue Française d'Aquariologie, Herpetologie 18(4):111-116.

Rapp Py-Daniel, L. H. \& Cox Fernandes, C. 2005. Dimorfismo sexual em Siluriformes e Gymnotiformes (Ostariophysi) da Amazônia. Acta Amazonica 35(1):97-110.

Regan, C. T. 1904. A monograph of the fishes of the family Loricariidae. Transactions of the Zoological Society of London 17(3): 191-350.

ReIs, R. E. Dos. 1983. Rineloricaria longicauda e Rineloricaria quadrensis, duas novas espécies de Loricariidae no sul do Brasil (Pisces, Siluriformes, Loricariidae). Iheringia, Série Zoologia, 62:61-80.

. 1998. Anatomy and phylogenetic analysis of the Neotropical callichthyid catfishes (Ostariophysi, Siluriformes). Zoological Journal of the Linnean Society 124:105-168.

Reis, R. E. DOS \& CARdoso, A. R. 2001. Two new species of Rineloricaria from southern Santa Catarina and northeastern Rio Grande do Sul, Brazil. Ichthyological Exploration of Freshwaters 12(4):319-332.

Reis, R. E. dos; Weber, C. \& Malabarba, L. R. 1990. Review of the genus Hypostomus Lacépède, 1803 from Southern Brazil, with descriptions of three new species. Revue Suisse de Zoologie 97(3):729-766.

Rodriguez, M. S. \& Miguelarena, A. M. 2005. A new species of Rineloricaria (Siluriformes: Loricariidae) from the Paraná and Uruguay River basins, Misiones, Argentina. Zootaxa 945: 1 - 15 .

Schaefer, S. A. 1997. The Neotropical cascudinhos: systematics and biogeography of the Otocinclus catfishes (Siluriformes: Loricariidae). Proceedings of the Academy of Natural Sciences of Philadelphia 148:1-120.

Recebido em maio de 2006. Aceito em setembro de 2007. ISSN 0073-4721

Artigo disponível em: www.scielo.br/isz 